\title{
Role of miRNAs in Alzheimer's Disease and Possible Fields of Application
}

\author{
Serena Silvestro, Placido Bramanti and Emanuela Mazzon * (D) \\ IRCCS Centro Neurolesi “Bonino-Pulejo”, Via Provinciale Palermo, Contrada Casazza, 98124 Messina, Italy \\ * Correspondence: emanuela.mazzon@irccsme.it; Tel.: +39-090-6012-8172
}

Received: 19 July 2019; Accepted: 14 August 2019; Published: 15 August 2019

\begin{abstract}
RNAs (or microRNAs) are a class of single-stranded RNA molecules, responsible for post-transcriptional gene silencing through binding to the coding region as well as $3^{\prime}$ and $5^{\prime}$ untranslated region of target genes. About $70 \%$ of experimentally detectable miRNAs are expressed in the brain and some studies suggest that miRNAs are intimately involved in synaptic function and in specific signals during memory formation. More and more evidence demonstrates the possible involvement of miRNAs in Alzheimer's disease (AD). AD is the most common form of senile dementia, a disease that affects memory and cognitive functions. It is a neurodegenerative disorder characterized by loss of synapses, extracellular amyloid plaques composed of the amyloid- $\beta$ peptide $(\mathrm{A} \beta)$, and intracellular aggregates of hyperphosphorylated TAU protein. This review aims to provide an overview of the in vivo studies of the last 5 years in the literature describing the role of the different miRNAs involved in AD. miRNAs hold huge potential as diagnostic and prognostic biomarkers and, at the same time, their modulation could be a potential therapeutic strategy against AD.
\end{abstract}

Keywords: Alzheimer's disease; miRNA; in vivo experimental models

\section{Introduction}

Alzheimer's disease (AD) is a progressive neurodegenerative disease and it is the most common cause of dementia worldwide. It is characterized by neuronal death, loss of synaptic function, and atrophy in different brain areas, with consequent loss of cognitive functions and memory [1-3]. The AD is characterized by neuritic (or amyloid) plaques and neurofibrillary tangles (NFTs) [1]. The diagnosis of $\mathrm{AD}$ is performed through neurological investigations, the administration of cognitive tests, the performance of specific neuroimaging tests, and cerebrospinal fluid tests [4]. Neuritic plaques are extracellular accumulations of beta-amyloid $(A \beta)$. Many studies have suggested that $A \beta$ regulates neuronal and synaptic activities. Its accumulation in the brain plays a crucial role in initiating the disease and triggering a complex pathological cascade, which leads to neuronal damage [5]. A $\beta$ peptide derives from the enzymatic proteolysis of the amyloid precursor protein (APP), a protein that physiologically plays an important role in brain homeostasis [6]. A first pathway involved in APP processing is the non-amyloidogenic $\alpha$-secretase-mediated pathway. APP cleavage by $\alpha$-secretase generates $\operatorname{sAPP} \alpha$, a soluble molecule that has a probable neuroprotective function. Indeed, this peptide plays an important role in the plasticity and survival of neurons and in the protection against cytotoxicity $[7,8]$. In healthy subjects, the degradation process of the APP appears to be operated mainly by $\alpha$-secretase. In contrast, in the subjects with $A D$, the $A \beta$ peptide is produced following a $\beta$ and $\gamma$-secretase-mediated amyloidogenic pathway [9]. In this way the APP is mainly processed by the $\beta$-secretase cleaving enzyme 1 (BACE1) which operates the first cut, generating sAPP- $\beta$ and a fragment consisting of 99 amino acids. The $\gamma$-secretase further cleaves this fragment from which a peptide of 40 amino acids and one peptide of 42 are generated, called $A \beta_{1-40}$ and $A \beta_{1-42}$, respectively $[10,11]$. $A \beta_{1-42}$ is more hydrophobic, amyloidogenic, and toxic $[12,13]$. In the extracellular space, $A \beta$ tends to deposit 
in insoluble fibrillar aggregates, which lead to the formation of the so-called amyloid plaques. These neuronal plaques trigger a reactive inflammatory process that irreversibly damages neurons $[14,15]$. Another protein involved in AD is the TAU, which under conditions of hyperphosphorylation leads to the formation of NFTs in the cell body of neurons. TAU is a protein that stabilizes microtubules and promotes vesicular-mediated transport. In neurons, microtubules are essential for maintaining neuronal structure, axonal transport, and neuronal plasticity [16]. In physiological conditions, the functioning of the TAU is given by a perfect balance between phosphorylation and dephosphorylation. In the etiopathogenesis of $\mathrm{AD}$, however, excessively phosphorylated TAU causes the formation of NTFs with consequent destabilization and neuronal death [17]. Two forms of AD have been identified: Familial AD (FAD), also known as AD early-onset and sporadic AD (SAD), characterized by late-onset. About $70 \%$ of the risk of developing FAD may be due to mutations in the APP, PSEN1, and PSEN2 genes [18]. The APP gene encodes for the amyloid precursor protein (APP), while the PSEN1 and PSN2 genes encode for presenilin 1 (PSEN1) and presenilin 2 (PSN2) proteins [19]. PSEN1 and PSEN2 are enzymes belonging to the class of proteases A that regulate the functions of the enzyme $\gamma$-secretase, responsible for cutting the amyloid protein. Mutations in PSEN1 and PSEN2 genes lead to the accumulation of $A \beta$. Instead, late-onset $A D$ is mainly associated with a polymorphism in the APOE gene encoding for apolipoprotein E (APOE), a protein involved in lipid metabolism [20,21]. In particular, the APOE4 isoform can influence the pathogenesis of AD by promoting the conversion of $A \beta$ into a fibrillar form and its deposition. In addition, APOE4 also appears to have adverse effects on $A \beta$ clearance. $A \beta$ is normally transported through the blood-brain barrier via protein 1 associated with the LDL receptor (LRP1) in the blood for the possible degradation in the liver. The APOE4 isoform has a low specificity toward LRP1, consequently, it slows the clearance of A $\beta$ and favors its accumulation [22]. Furthermore, recent studies have shown that some modifying factors such as lifestyle and diet reduce the risk of occurrence of AD. Specifically, physical activity stimulates neurogenesis, synaptic plasticity, and the production of neurotrophins [23]. In addition, both physical activity and a diet enriched with polyphenols, coumarin, catechins, resveratrol, vitamin E, and omega-3 fatty acids have an anti-inflammatory effect and reduce oxidative stress, two important factors of the etiopathogenesis of AD [24,25]. MicroRNAs (miRNAs), a large family of small noncoding RNAs, are important regulators of gene expression at the transcriptional and post-transcriptional level. They can regulate gene silencing. About $70 \%$ of all identified miRNAs are expressed in the brain [26]. Several studies, in fact, show that the misregulation and alterations of specific miRNAs could contribute to the etiopathogenesis of $\mathrm{AD}[27,28]$. The discovery that miRNAs interfere with the expression of genes involved in AD has suggested the development of strategies that provide for the use of miRNAs as therapeutic agents. Specifically, the researchers have used an approach that involves the use of single-stranded antisense oligonucleotides, which block the transcription of miRNAs involved in AD. Alternatively, double-stranded synthetic oligonucleotide miRNAs can be used. In this way, it enhanced the expression of some miRNAs that counteract $A \beta$ and TAU accumulation [29]. One of the major challenges in the field of miRNA therapy in AD treatment remains effective delivery to target the brain. In particular, the delivery of miRNAs into the central nervous system is very critical as the biochemical and biological properties of the blood-brain barrier. In the preclinical studies delivery of miRNAs into the brain is performed frequently through intracerebroventricular injections by the use of an implanted catheter connected to a pump [30]. Alternatively, the intrathecal route can be used, delivering miRNAs in the subarachnoid space. This review aims to provide an overview of the in vivo studies that describe the role of different miRNAs in AD and their possible fields of application in the last 5 years. 


\section{2. miRNA}

MiRNAs (or microRNAs) are small noncoding RNAs (21-25 nucleotides) that play a significant role in the post-transcriptional regulation of gene expression in eukaryotes [31]. The miRNAs exert their action in post-transcriptional gene silencing, binding to the coding region as well as $3^{\prime}$ and $5^{\prime}$ untranslated region (UTR) of the messenger RNAs (mRNAs). miRNAs perform a "hetero-silencing" mechanism, blocking the translation or degrading target mRNA. The same miRNA can target different mRNAs; at the same time, a single mRNA can be regulated by different miRNAs. The transcription of the primary miRNAs (pri-miRNA) is carried out by the RNA polymerase II, toward which they show a particular affinity. The affinity for RNA polymerase II must be attributed to the presence in the primary transcript of promoters that contain typical characteristics of RNA polymerase II [32]. The miRNAs originate from a long transcript characterized by a double-stranded structure known as pri-miRNA. In the nucleus, the pri-miRNA is recognized by the Pasha protein (Partner of Drosha) which is associated with RNAase type III Drosha. Pasha orients the catalytic domain of Drosha so as to allow the enzyme to cut the pri-miRNA, obtaining transcripts of about 70 nucleotides called miRNA precursors (pre-miRNA) [33]. Subsequently, the pre-miRNAs complexed by RAN-GTP proteins and through the exportin 5 are transported from the nucleus to the cytoplasm [34,35]. In the cytoplasm, the pre-miRNA undergoes a second cut by another RNase III, Dicer, generating RNA molecules of about 22 nucleotides, called miRNAs. After cleavage, a single strand of miRNA is incorporated into the complex known as "RNA-induced silencing complex" (RISC), while the other strand is degraded. Within RISC, mature miRNA binds to and regulates specific target mRNAs [36]. miRNAs can induce post-transcriptional gene silencing using two different mechanisms depending on the complementarity between the miRNA and its mRNA target. The miRNAs that bind perfectly complementary areas of their target mRNA induce its degradation by deadenylation, cap removal, and exonucleolytic digestion of mRNA. In contrast, miRNAs that bind mRNA with imperfect complementarity cause a translation block. This block can occur by repression of the translation during the initial phase or during the elongation phase. Alternatively, miRNAs can repress translation even by inducing premature ribosome detachment [37].

miRNAs are involved in the development of a variety of pathological conditions such as cardiovascular diseases, cancer, arthritis, cataracts, osteoporosis, diabetes/obesity, and hypertension. They are also implicated in various neurodegenerative diseases such as AD, Huntington's disease, Parkinson's disease, amyotrophic lateral sclerosis, and schizophrenia [38].

The fine regulation of genes associated with pathologies through miRNAs could be an important mechanism to maintain neuronal homeostasis and allow the neuronal circuits to respond adequately to environmental insults [39].

\section{3. miRNA and Experimental Models of Alzheimer's Disease}

Several studies evaluated the role of miRNAs in AD mouse models. The most used AD animal models are the APP/PSEN1 transgenic models, developed after the discovery that mutations of the $A P P$ and PSEN1 genes are responsible of the familial forms of AD.

Lin, et al. [40] investigated the effects of osthole on miRNA expression and the consequent influence in AD. Osthole, a coumarin derivative, has several anti-inflammatory, anti-apoptosis, anti-oxidative properties [41] and it is already known to have a therapeutic role in AD [42]. The effects of osthole were evaluated in APP/PSEN1 mice. APP/PSEN1 are double transgenic mice expressing a chimeric precursor protein of human amyloid (Mo/HuAPP695swe) and a mutant human presenilin 1 (PS1-dE9). The results of the in vivo study showed that the osthole induced the upregulation of miRNA-101a-3p. Furthermore, western blot analysis performed in hippocampal and cortex extracts of mice revealed that the expression of APP protein and A $\beta$ decreased in the experimental group treated with osthole. At the same time, an in vitro study was performed using human neuroblastoma cells SH-SY5Y transfected with GFP-APP595/596 lentivirus with overexpression of APP. According to the results obtained from the in vivo study, treatment with osthole showed an increase in the expression of miRNA-101a-3p, a 
reduce cell damage, and an increase in viability. In order to demonstrate the mechanism by which osthole influences miRNA-101a-3p by regulating the expression of the APP protein, the same cells were transfected with the miRNA-101a-3p inhibitor. In this experimental condition, it was observed an increase in the expression of the APP and A $\beta$ protein.

Higaki et al. [43] conducted a study in order to correlate the differential expression of the miRNA-200 family (miRNA-200a, -141, -429, -200b, -200c) in the initial phases of AD in the mouse brain Tg2576. Tg2576 mice overexpress the APP protein (Swedish KM670/671NL mutation). Analysis of the total RNA microarray extracted from cortical tissues of mice revealed that miRNA-200a, -141, $-429,-200 \mathrm{~b}$, and $-200 \mathrm{c}$ were upregulated only in Tg2576 mice of 10 months of age. These results suggest that some miRNAs may respond to the early $A \beta$ accumulation. In addition, an in vitro study was conducted on primary murine neuronal cells (PMNC) isolated from the cortical tissues of mice in order to verify if the expression of miRNA-200b and miRNA-200c are altered in response to neuronal damage induced by $A \beta_{1-42}$. The treatment with $A \beta$ of the PMNC cells induced the upregulation of miRNA-200b or -200c. Subsequently, the cells were transfected with miRNA-200b/c demonstrating that the upregulation of miRNA-200b and miRNA-200c reduced the secretion of $A \beta$ in conditioned medium. In order to evaluate the effect of miRNA-200b/c in vivo, $\mathrm{Tg} 2576$ mice were treated with miRNA-200b/c by intracerebroventricular injection. This experiment confirmed what was obtained in vitro, suggesting that miRNA-200b and miRNA-200c may be potential therapeutic targets in AD.

Liu et al. [44] conducted a study to evaluate the expression of miRNA-220b, miRNA-135a, and miRNA-429 in the hippocampus of APP/PSEN1 transgenic mice. Microarray miRNA analysis showed that these miRNAs were significantly upregulated. In addition, this analysis was supported by bioinformatics tools that disclose the potential interaction between APP and BACE-1, an enzyme responsible for the production of $A \beta$. In order to verify the effects of these miRNAs on the expression of APP and BACE-1, an in vitro study was also conducted using primary hippocampal neurons isolated from mice and SH-SY5Y cells transfected with oligonucleotides miRNA-135a, -200b, and -429 . The results obtained show that miRNA-135a repressed the expression of BACE-1, whereas miRNA-200b and miRNA-429 decreased the expression of the APP. Instead, cells transfected with the miRNA-135a inhibitor oligonucleotide induced a significant upregulation of BACE-1. Whereas, in cells transfected with miRNA-200b and miRNA-429 inhibitor oligonucleotides, a significant upregulation of the APP protein was observed. These data were supported by the clinical study that showed a decrease only of miRNA-135a and -200b levels in serum and cerebrospinal fluid of AD patients compared to healthy subjects.

Zhang et al. [45] investigated the involvement of miRNA-200a-3p upregulation in A $\beta$-induced neuronal apoptosis by inhibiting the silent information regulator transcript-1 (SIRT1) in APP/PSEN1 mice. SIRT1 can deacetylate histone, nonhistone proteins, other transcription factors and is involved in the regulation of cellular senescence, gene transcription, energy balance, and oxidative stress. The effects of SIRT1 could act upstream and downstream of A $\beta$ [46]. An increase in SIRT1 is typically related to the neuroprotection in neurodegenerative disorders [47]. In hippocampus of APP/PSEN 1 mice and in vitro in pheochromocytoma PC12 cells treated with $A \beta_{25-35}$, elevated expression of miRNA-200a-3p and a reduced level of SIRT1 were found. In particular, PC12 cells treated with A $\beta_{25-35}$ showed a higher level of expression of cleaved-caspase-3, while these levels decreased when the cells were transfected with a miRNA-200a-3p inhibitor. In addition, when instead PC12 cells were transfected with plasmid vectors that host the SIRT1 and subsequently co-transfected with miRNA-200a-3p inhibitors, it was observed that the suppression of miRNA-200a-3p attenuates $\mathrm{Ab}_{25-35}$-induced apoptosis. 
miRNA-29a, miRNA-29b, and miRNA-29c are a class of miRNAs known to regulate BACE-1 expression and pathogenesis of AD [48]. Yang et al. [49] studied the role of miRNA-29c in AD. Peripheral blood samples from AD patients showed a decrease in miRNA-29c expression levels and a significant increase in BACE-1 expression compared to healthy subjects. In addition, the researchers evaluated the role of miRNA-29c in in vitro and in vivo studies. Primary hippocampal neurons were obtained from senescence-accelerated mouse-resistant 1 (SAMR1) and were transfected with miRNA-29c or miRNA-29c inhibitors. Results showed that miRNA-29c overexpression significantly reduced BACE-1 expression levels. However, an inverse result was obtained when the cells were treated with the miRNA-29c inhibitor. This molecular mechanism was subsequently confirmed in in vivo study, using AD senescence-accelerated mouse prone 8 (SAMP8). SAMP8 mouse is a mutant of spontaneous crosses, characterized by an accelerated aging phenotype. After mimic injections of miRNA-29c in the hippocampus of mice showed significantly increased levels of miRNA-29c compared to control mice. The in vivo study confirmed the in vitro results showing that miRNA-29c upregulation significantly reduced the expression levels of BACE- 1 and A $\beta$ proteins.

Furthermore, Zong et al. [50] studied mRNA-29c levels in the APP/PSEN1 mouse model. The results showed that miRNA-29c levels were significantly increased in the hippocampus of mice. However, they were significantly decreased in the frontal cortex. This discrepancy in the miRNA-29c level between the hippocampus and the frontal cortex may indicate that the various miRNAs are expressed in a spatially controlled manner. The immunohistochemical observation also revealed that in the hippocampus of the young APP/PSEN1 mice, where the levels of miRNA-29c were high, neuron navigator 3 (NAV3) protein levels were decreased. NAV3 is expressed predominantly in the central and peripheral nervous system and appears elevated in the AD brain. Although the biological function of the mammalian NAV3 protein in the brain remains totally unknown, it appears to play a key role in axon guidance [51]. The inverse expression of miRNA-29c and NAV3 was also observed in neuroblastoma (Neuro2A) cells that were transfected with the miR-29c and successively with the probe directed against miRNA-29c. It is not yet clear whether the enhanced expression of NAV3 in the AD brain reflects some pathogenetic changes or is attributable to a defense mechanism against neurodegenerative events. However, the results of the present study may show that miR-29a underexpression affects neurodegenerative processes by increasing the regulation of NAV3 and other miR-29a targets, such as BACE-1.

The study conducted by Jiang et al. [52] aimed to analyze the effect of miRNA-137 in APP/PSEN1 transgenic mice. MiRNA-137 is a regulator of neuronal development and cognitive function, which also appears to be involved in AD $[53,54]$. The researchers also evaluated the regulatory effect of miRNA-137 on the transcription of its potential target gene, calcium voltage-gated channel subunit alpha- $1 \mathrm{C}$ (CACNA1C). CACNA1C is a gene that encodes the alpha 1C subunit of the voltage-dependent calcium channel of type L CaV1.2 [55] and it is responsible for the regulation of intracytoplasmic calcium $\left(\mathrm{Ca}^{2+}\right)$ in neurons. As has been shown, an increase in the $\mathrm{Ca}^{2+}$ influx through CaV1.2 contributes to neuronal dysfunctions, as found in AD [56]. The results revealed a decrease in miRNA-137 levels and an increase in $A \beta$ and CACNA1C protein levels in the hippocampus and in the cerebral cortex of the AD mouse. The role of miRNA-137 in CACNA1C expression was also validated by evaluating the expression of CACNA1C in human SH-SY5Y neuroblastoma cells treated with or without $\mathrm{A} \beta_{1-42}$ and subsequently transfected with miRNA-137 mimics or miRNA-137 inhibitors. The results confirmed the data obtained in the in vivo study demonstrating that the downregulation of miRNA-137 determines an increase in $\mathrm{Ca}^{2+}$ levels and a reduction of $\mathrm{A} \beta_{1-40}$ and $\mathrm{A} \beta_{1-42}$. These results indicate that an increase in this miRNA could cause a decrease in $\mathrm{Ca}^{2+}$ levels in neurons, improving neuronal dysfunctions typical of AD. 
The aim of the study conducted by Sierksma et al. [57] was to understand if miRNAs altered are associated with progressive memory deterioration in AD. Transgenic mice for APP (APPtg) and for TAU (TAUtg) were used. MiRNAseq revealed that miR-10a-5p, miR-142a-5p, miR-146a-5p, miR-155-5p, miR-211-5p, and miR-455-5p are commonly upregulated in both APPtg and TAUtg mice. Four of these, miR-142a-5p, miR-146a-5p, miR-155-5p, and miR-455-5p, were upregulated also in patients with AD. Differential analysis of miRNA expression between APPtg and TAUtg mice showed that the overexpression of these miRNAs in TAUtg mice appears starting from four months of age, while the miRNA disorders in APPtg mice mainly occur when $A \beta$ has accumulated at ten months of age. In order to evaluate whether the upregulation of these miRNAs is sufficient to induce the cognitive alterations observed in the APPtg and TAUtg mice, intracerebroventricular injections of a single miRNA oligonucleotide or a mix of the six miRNAs were performed in C57BL/6J. These injections lead to a significant increase in hippocampal expression of each miRNA; however, they do not cause serious cognitive deficits. Therefore, these findings suggest that miRNAs could have a protective effect on AD progression.

The study conducted by Zhou et al. [58] proposed to explore the effect of the interaction between miRNA-330 and guanine nucleotide exchange factor 1 (VAV1), enzymes that catalyze the exchange of guanosine diphosphate (GDP) by guanosine triphosphate (GTP) in Rho GTPases proteins, whose activity is involved in AD. Rho GTPases are involved in synaptic plasticity and showed a relationship with APP synthesis and A $\beta$ production [59]. MiRNA-330 overexpression is associated with brain development and it functions as a regulator of protein expression and regulates the development and progression of the disease [60]. For the study, C57BL/6J mice were used and subjected to intraperitoneal injection with D-galactose for 4 weeks for inducing the AD model. The results obtained showed downregulation of miRNA-330, a significant increase in the expression of the VAV1 and A $\beta$ proteins in the cerebral cortex of the AD mouse. In parallel, an in vitro study was conducted on cells of primary neurons collected from mice. In order to induce overexpression of miRNA-330, primary neurons were transfected with miRNA-330. The first result shows that miRNA-330 overexpression inhibited VAV1, that in turn blocks mitogen-activated protein kinase (MAPK) signaling pathway. MAPK are serine-threonine kinases that mediate a variety of cellular activities including proliferation, differentiation, survival, death, and cell transformation. Activated MAPK signaling pathways contribute to the pathogenesis of AD through various mechanisms including phosphorylation and stabilization of APP, the transcriptional and enzymatic activation of $\beta$ - and $\gamma$-secretase, and the induction of neuronal apoptosis [61]. The second result of the study shows that miRNA-330 upregulation inhibits the production of $A \beta$ always through the MAPK signaling pathway. It appears that MAPK blocks the $\alpha 7$ nicotinic acetylcholine receptor resulting in a reduction in the uptake and accumulation of $A \beta$ [62]. In addition, the upregulation of miRNA-330 suppresses oxidative stress and improves mitochondrial dysfunction always via the MAPK signaling pathway. In this way, upregulation of miRNA-330 inhibits VAV1 and block MAPK signaling pathway determining a reduction of $A \beta$, a suppress of oxidative stress, and improvement of mitochondrial dysfunction.

miRNA-34a is involved in several AD pathways such as $A \beta$ deposition and cognitive dysfunction. Jian et al. [63] evaluated the role of this miRNA in $A \beta$ production and clearance. For the study, APP/PSEN1 mice were compared to the miRNA-34a knockout APP/PSEN1 (miRNA-34a KO/APP/PSEN1) mice. In APP/PSEN1 mice the level of miRNA-34a increased, consistent with the increase of A $\beta$. In contrast, in miRNA-34a KO/APP/PSEN1 mice the data showed that the number and area of amyloid plaques were significantly decreased, and a significant reduction in behavioral dysfunction was also observed. This suggests that miRNA-34a upregulation may contribute to the promotion of AD pathology. Furthermore, the role of miRNA-34a in the processing of APP was evaluated. The results showed that the improvement observed in miRNA-34a KO/APP/PSEN1 mice is due to the decrease in APP amyloidogenic processing by $\beta$-secretase activity and BACE- 1 expression inhibition. In agreement, these results are in line with those of $\mathrm{Xu}$ et al. [64] that had observed an increase in miRNA-34a expression in APP/PSEN1 mice, with A $\beta$ production, amyloid 
plaque deposition, and cognitive deficits. In contrast, the lack of miRNA-34a in knockout mice significantly reduced cognitive deficits and inhibited the amyloidogenic processing of the APP protein. Moreover, researchers also evaluated the expression profile of miRNA-34a-3p and miRNA-34a-5p in the initial phase of AD pathology in APP/PSEN1 mice compared to miRNA-34a KO/APP/PSEN1. Bioinformatics tools predicted that miRNA-34a-5p mainly targeted to $N$-methyl-D-aspartate (NMDA), while miRNA34-3p to $\alpha$-amino-3-hydroxy-5-methyl-4-isoxazolapropionic (AMPA). AMPA and NMDA are two dynamic receptors on the synaptic membrane involved in synaptic plasticity and information storage [65]. Therefore, the level of mRNA and proteins of multiple subunits of AMPA receptors and NMDA receptors in the hippocampus were determined. It was observed that several types of subunits of AMPA and NMDA receptors were markedly upregulated in APP/PSEN1 mice with miRNA-34a deficiency. Since, in the mature central nervous system, the composition of the subunit of these receptors influences multiple synaptic functions including stabilization, neurotransmission, and even neuronal activity $[66,67]$, a downregulation can decrease synaptic strength, resulting in cognitive impairment. In addition, it appears that this miRNA also appears to be involved in AD anxiety disorder in AD. Specifically, Zhang et al. [68] observed the correlation of miRNA-34a with metabotropic glutamate receptor 7 (GRM7). GRM7 is an excitatory neurotransmitter related to excitatory synaptic transmission, neuronal development and death, synaptic plasticity, and some neurological diseases such as anxiety and depression [69]. The triple transgenic mouse model of AD (3xTg-AD) was used for the study. 3xTg-AD mice contain three mutations associated with FAD (Swedish app, MAPT P301L, and PSEN1 M146V). Behavioral tests were performed on mice that revealed anxiety-like behaviors. Subsequently, the hippocampus was isolated from mice to evaluate the expression of miRNA-34a and e GRM7. The result of this work showed significant miRNA-34a expression in the hippocampus of 3xTg-AD mice and downregulation of GRM7. The results of this study suggest that the anxious behavior observed in 3xTg-AD mice could be related to the dysregulation of miRNA-34a/GRM7 observed in the hippocampus.

Recently, it was shown that a new pathway for improving endogenous repair can be obtained by overexpression of specific miRNAs [70]. In the study conducted by Ghasemi-Kasman et al. [71], it was studied whether the miRNA-302/367 cluster is capable of inducing the conversion of astrocytes into neurons. The miRNA-302/367 cluster, composed of five members, miRNA-367, miRNA-302d, miRNA-302a, miRNA-302c, and miRNA-302b, is involved in the regulation of cell proliferation, differentiation, and reprogramming [72]. Researchers for the study used the AD mouse model induced by intracerebroventricular injection of streptozotocin (STZ). Lentiviral particles of miRNA-302/367 were injected into the hippocampal dentate gyrus together with the intraperitoneal injection of valproate (VPA). VPA has the ability to regulate the expression of neuronal genes related to neurodegenerative disorders, increases neuronal survival and reduces the vulnerability of neural cells to damage. Furthermore, VPA showed the ability to activate neprilysin, the main $\beta$-degrading enzyme of amyloid [73]. The results obtained showed that miRNA-302/367 in combination with VPA improved spatial learning and memory that were compromised by STZ injection. Furthermore, two weeks after the injection of miRNA-302/367 clusters, immunostaining against GFAP as an astrocyte marker confirmed that hippocampal activated astrocytes were reprogrammed to neurons in the animal model AD.

The study conducted by Hong et al. [74] was mainly aimed at identifying the level of miRNA-125b circulating in APP/PSEN1 mice and its correlation with cognitive function. Recently, it was shown that circulating miRNA-125b levels were downregulated in $\mathrm{AD}$ and could be potential biomarkers of disease [75]. The results of this study showed the serum miRNA-125b level was significantly downregulated in APP/PSEN1 mice. Furthermore, the analysis of expression of circulating miRNA revealed that miRNA-9 and miRNA-191-5p were also downregulated, on the contrary, miRNA-28-3p was upregulated. Moreover, a positive correlation was demonstrated only between miRNA-125b and the decline of cognitive function. In addition, the level of this miRNAs in APP/PSEN1 transgenic mice treated with epigallocatechin gallate (EGCG), an active component of green tea, was also studied. 
This compound appears to be effective as a potential therapeutic agent for $\mathrm{AD}$, suppressing cognitive dysfunction, increasing learning ability, and reducing damage induced by oxidative stress [76,77]. In mice treated with EGCG the levels of these miRNAs were reversed compared to untreated mice and only miRNA125b showed a positive correlation with cognitive function. In order to further identify the relationship between miRNA-125b and AD, an in vitro model was also performed, treating SH-SY5Y cells with EGCG. The level of miRNA-125b was significantly increased in accordance with the results obtained in in vivo study.

The purpose of the study conducted by Tang et al. [78] was to examine the role of miRNA-139 in spatial memory, fear conditioning, and recognition memory. For the study, the SAMP8 strain was used as an AD model and SAMR1 as a control strain. Compared to control mice, miRNA-139 expression was significantly higher in the hippocampus of the SAMP8 mice. In order to understand the role that miRNA-139 exerts on learning and memory, injections of miRNA-139, miRNA-139 inhibitor, and control miRNA were performed in the dentate gyrus of SAMP8 and SAMR1 mice. The results of the study show that the downregulation of miRNA-139 expression improved spatial memory, the recognition of new objects, long-term memory, and contextual fear conditioning. The study also sought to understand the potential targets of miRNA-139, demonstrating that miRNA-139 inhibits cannabinoid receptor type 2 (CB2) expression. CB2, a membrane marker of activated microglia cells, is involved in synaptic plasticity and neuroprotection and appears to modulate hippocampal function in the context of AD [79]. Furthermore, it was observed that $\mathrm{CB} 2$ deficiency affects the ability to activate microglia and the recruitment of macrophages in the brains of $\mathrm{AD}$ mice by reducing neuroinflammation $[80,81]$. In this way, miRNA-139 downregulation by inhibiting CB2 decreases responses to pro-inflammatory stimuli and acts as a regulatory factor in the pathogenesis of AD.

MiRNAs are key factors in development, neurogenesis, and synaptic functions in the central nervous system. The study conducted by Lee et al. [82] investigated the role of miRNA-188-5p in restoration of the synaptic and cognitive deficits in AD. For the study, 5xFAD transgenic AD mice were used. These mice express human APP and PSEN1 transgenes with a total of five AD-linked mutations: three familial mutations of APP 695 (Swedish, Florida, and London mutation) and two PSEN1 mutations (M146L and L286V). The results of the study show that the downregulation of miRNA-188-5p expression contributes to the pathogenesis of $\mathrm{AD}$ by inducing synaptic dysfunction and cognitive deficits. The expression of miRNA-188-5p was also downregulated in brain tissues from patients with AD compared to healthy subjects of corresponding age. In parallel, an in vitro study was conducted on primary cells of hippocampal neurons treated with $A \beta_{1-42}$ and transfected with miRNA-188-5p oligonucleotides. Treatment with oligomeric $A \beta_{1-42}$ decreased miRNA-188-5p expression in primary cultures of hippocampal neurons. In contrast, it was observed that miRNA-188-5p overexpression alleviated the decrease in dendritic spine density in primary hippocampal neurons exposed to $A \beta$. This result showed that miRNA-188-5p improved $A \beta_{1-42}$-mediated synaptic dysfunction. In order to validate also in vivo, these results were performed injection of miR-188-5p, subcloned in a lentiviral vector, in the hippocampus of 5XFAD mice. After 3 weeks of injection, the overexpression of miRNA-188-5p has determined the improvement of alterations in cognitive function and synaptic transmission, confirming the results obtained from the in vitro study.

The miRNAs, in addition to influencing the production process of $A \beta$, are also involved in the phosphorylation and dephosphorylation of the TAU protein, responsible for the formation of NFT. MiRNA-132 is downregulated in the brain of AD patients [83,84]. The aim of the study conducted by Salta, et al. [85] was to characterize the functional impact of the downregulation of miRNA-132 on the AD pathology by identifying the molecular networks underlying these effects. For the experiment, the APP/PSEN1 mice were treated with intracerebroventricular injections of miRNA-132 and miRNA-132 inhibitor. Following these injections, it was observed that the downregulation of miRNA-132 was correlated with an increase of the peptide $A \beta$ and phosphorylated TAU in the hippocampus of APP/PSEN1 mice. In contrast, the upregulation of miRNA-132 caused a reduction in $\mathrm{A} \beta$ and phosphorylated TAU. The transcriptome microarray analysis using the prefrontal cortex of 
patients with $\mathrm{AD}$ and healthy individuals demonstrated that inositol 1,4,5-trisphosphate 3-kinase $\mathrm{B}$ (ITPKB) was a possible miRNA-132 target. ITPKB is a kinase, known to phosphorylate ERK1/2 leading to an increase in TAU phosphorylation [86,87]. At the same time, ITPKB also influences the activity of BACE- 1 which leads to the generation of A $\beta$. The interaction between miRNA-132/ITKB would explain the effect on reducing $A \beta$ and TAU in APP/PSEN1 mice. In order to confirm the link between miRNA-132 and ITPKB, human embryonic kidney (HEK293) cells overexpressing human APPS were transfected with a miRNA-132 inhibitor oligonucleotide and co-transfected with an ITPKB siRNA oligonucleotide. In vivo experiments confirmed a significant increase in $A \beta_{1-40}$ and $A \beta_{1-42}$. While, the inhibition of ITPKB has determinate a downregulation of ITPKB with a consequent reduction in $A \beta$, demonstrating the involvement of this kinase in the production of $A \beta$. This data was further confirmed in in vivo study by intracerebroventricular injections of ITPKB siRNA in mice.

Moreover, in another study conducted by Smith et al. [88], the involvement of miRNA-132 on TAU expression was observed. In particular, the role of the miRNA-132/212 cluster in AD was evaluated in this study. This cluster appears to be downregulated in AD. Numerous studies show that miRNA-132 and miRNA-212 play an important role in synaptic plasticity and memory formation [89]. In in vivo study, miRNA-132/212 knockout mice were used and it was observed that the deletion of miRNA-132/212 caused increased phosphorylation and accumulation of TAU. Autophagy was observed to be one of many factors involved in TAU aggregation [90]. The result of the western blot analysis performed in the brains of these miRNA-132/212 deficient mice confirms that the autophagic process is compromised in the absence of miRNA-132/212. The role of miRNA-132/212 in the regulation of TAU in AD has been further confirmed by treating 3xTg-AD mice with miRNA-132 mimic. After three weeks, the treatment produced better long-term memory deficits and a significant reduction in phosphorylated TAU.

The same research group performed a direct follow-up of the previous study. In this work, Hernandez-Rapp et al. [91] investigated the impact of miRNA-132/212 loss in production, cleavage, and clearance of $A \beta$. The results showed that the genetic deletion of miRNA-132/212 promotes the production of $A \beta$ and the formation of amyloid plaques in 3xTg-AD-miRNA-132/212 knockout mice. In order to determine the target genes of the miRNA-132/212 cluster with documented roles in the regulation of A $\beta$ metabolism, RNA extracts of hippocampi of 3xTg-AD-miRNA-132/212 knockout mice used for performing RNA sequencing. The results showed that SIRT1, MAPK1/ERK2, and TAU were interesting miRNA-132 targets that were found to be upregulated in 3xTg-AD mice. These results were confirmed in in vitro study using mouse neuro2a-cells and human HEK293 transfected with miRNA-132. Both cell lines were overexpressing APP. The results showed that in the cells transfected with miRNA-132 the $A \beta_{1-40}$ and $A \beta_{1-42}$ levels were reduced, while SIRT1 was downregulated. Normally, an increase of SIRT1 is responsible for neuroprotective effects, therefore, its downregulation determined by upregulation of miRNA-132 contributes to the increase of $\mathrm{A} \beta$ and to the deposition of senile plaque in $\mathrm{AD}$.

Wang et al. [92] investigated the relationship between miRNA-146a, TAU-hyperphosphorylation, and rho-associated, coiled-coil-containing protein kinase 1 (ROCK1). The ROCK1 protein appears to be responsible for binding to protein phosphatase and tensin homolog (PTEN) involved in TAU dephosphorylation [93]. SH-SY5Y cells were transfected with miRNA146a. The miRNA-146a overexpression in SH-SY5Y cells caused a significant increase in TAU phosphorylation and simultaneously inhibited the translation of the ROCK1 protein. In addition, in order to evaluate the involvement of PTEN in this process, the SH-SY5Y cells were transfected with siRNA ROCK1. Transfection with ROCK1 siRNA resulted in a decrease in ROCK1 protein levels, reduced PTEN phosphorylation, and increased TAU phosphorylation. These data demonstrate how the expression of miRNA-146a by suppressing ROCK1 caused a reduction in PTEN phosphorylation and TAU hyperphosphorylation. The in vivo study was conducted using 5xFAD mice treated with injections of a miRNA-146a inhibitor in the intra-hippocampal region. This treatment induces an increase of ROCK1 protein level and suppression of TAU hyperphosphorylation. This result demonstrates that 
miRNA-146a contributes to the pathogenesis of $\mathrm{AD}$ and its inhibition could be a valid application as in vivo therapy.

Many miRNAs are implicated in amyloid- $\beta$ and TAU alterations; however, alterations in synaptic plasticity and neuronal loss are two important features shown in patients with AD. The study conducted by Rodriguez-Ortiz et al. [94] aimed to identify miRNAs that play a critical role in synaptic plasticity underlying the progression of AD. A significant upregulation of miRNA-181 was observed in the dorsal and ventral hippocampus of 3xTg-AD mice with plaques and tangles. Bioinformatics tools were used to identify potential miRNA-181 targets with particular attention to proteins that are relevant to neuronal and synaptic plasticity. SIRT1 and the c-Fos transcription factor were identified as possible miRNA-181 targets. Both SIRT-1 and c-Fos are proteins involved in memory consolidation [95]. Protein levels of these potential targets evaluated in the ventral hippocampus of 3xTg-AD mice were significantly decreased. This result was also confirmed in the in vitro study, transfecting SH-SY5Y cells with miRNA-181. In this way, the downregulation of SIRT1 determined by the overexpression of miR-181 favors the development of $A \beta$. Similarly, reduced levels of c-Fos can contribute to cognitive impairment.

Instead, the miRNA-181c was studied by Zhou et al. [96]. For the study, SAMP8 mice were used and a significant decrease in miRNA-181c was observed in the hippocampus of SAMP8. Bioinformatics analysis revealed that miRNA-181c could be involved in the regulation of axon guidance, MAPK signaling, dorsal-ventral axis formation, and long-term depression. Furthermore, the results of a luciferase assay on HEK293 cells showed that miRNA-181c overexpression affects the 3'-UTR region of collapsin response mediator protein 2 (CRMP2). The CRMP2 protein is an intracellular protein expressed mainly in areas of high plasticities, such as the adult olfactory bulb, the cerebellum, and the hippocampus [97]. CRMP2 is also involved in the assembly of microtubules in neurons. Nevertheless, it seems that the hyperphosphorylation of CRMP2 protein is an early event in AD progression [98]. In order to further confirm whether miRNA-181c could regulate the translation of CRMP2, an in vitro study was also performed, transfecting miRNA-181c in HT-22 hippocampal neuronal cells. The results showed that the overexpression of miRNA-181c downregulates the expression of CRMP2 proteins. Consequently, the low expression of miRNA-181c observed in the hippocampus of SAMP8 mice could lead to an increase in the level of CRMP2 protein in AD mice, playing a potential role in the pathogenesis of $\mathrm{AD}$.

Another miRNA involved in synaptic plasticity that plays a critical role in the memory deficits observed in patients with AD is miRNA-206. The aim of the study conducted by Tian et al. [99] was to determine the interaction between brain-derived neurotrophic factor (BDNF) and miRNA-206. BDNF is the most widely expressed neurotrophin in the central nervous system [100] and is involved in neurite growth, directional guidance, induction of long-term potentiation, and neurotransmitter release [101]. Several studies have shown that BDNF showed protective effect in AD both in in vivo [102] and in vitro experiments [103]. The results of the study showed that miRNA-206 was upregulated in hippocampal tissue, cerebrospinal fluid, and plasma of APP/PSEN1 transgenic mice. In order to understand how this miRNA is involved in BDNF alteration, BDNF levels have been assayed in mice. The results showed that the BDNF level in hippocampal tissue in APP/PSEN1 mice was decreased. In addition, researchers have shown that BDNF plays an important role in neuronal vulnerability and neuronal death. Primary neurons of the hippocampus from wild type and APP/PSEN1 mice were treated with extracellular $A \beta_{1-42}$ or staurosporine or glutamate. The results induced more severe cell death in APP/PSEN1 neurons compared to wild type neurons. Subsequently, the administration of exogenous BDNF decreased the vulnerability in the primary neurons subjected to different types of insults, confirming its protective role of BDNF. Therefore, an alteration of miRNA-206 contributes to the pathology of $\mathrm{AD}$ through the downregulation of BDNF. 
Macroautophagy is another process that can be regulated by miRNAs. It is a mechanism responsible for delivering cellular materials and organelles to lysosomes for degradation. In neurons, constitutive macroautophagy is involved in the maintenance of cellular homeostasis essential for cell survival [104]. On the contrary, induction of autophagy initiates a form of programmed cell death in some cellular populations [105], determining the loss of neural homeostasis that was responsible for AD. The purpose of the study conducted by Zhang et al. [106] is to investigate the role of miRNA-214-3p in the regulation of autophagy in SAD. In cerebrospinal fluid from patients with SAD was observed downregulation of miRNA-214-3p. In the in vivo experiment, the researchers showed the downregulation of miRNA-214-3p also in hippocampal neurons of SAMP8 mice. The in vitro study, transfecting the primary hippocampal neurons of SAMP8 with miRNA-214-3p, miRNA-214-3p inhibitor, or scrambled RNA as a negative control, showed that miRNA-214-3p overexpression in primary neurons from SAMP8 mice inhibited autophagy. Inhibition of autophagy was demonstrated by reduced levels of LC3 $\beta I I$ and Beclin1, reduced number of autophagosome vesicles, and decrease of caspase-mediated apoptosis. In contrast, miRNA-214-3p inhibitors promoted autophagy and apoptosis in SAMP8 mice neurons. Finally, in order to evaluate the role of miRNA-214-3p in the regulation of autophagy and apoptosis, miRNA-214-3p or scrambled RNA (negative control, NC) were injected into SAMP8 mice. The results showed that the treatment with miRNA-214-3p had attenuated neuronal apoptosis and improved behavioral performance. These data suggest that the overexpression of miRNA-214-3p suppresses macroautophagy.

The study conducted by Li et al. [107] aimed to understand the role of miRNA-574 in early AD in 5-month APP/PSEN1 mice. The results showed a significant synaptic loss and high levels of $A \beta_{1-42}$, with consequent cognitive deficits. The study also wanted to find out if there was a miRNA in the hippocampus linked to synapse-associated proteins in the early phase of AD development. The microarray miRNA assay was performed in the hippocampus tissue of wild type and APP/PSEN1 mice. The results showed that miRNA-382, miRNA-711, and miRNA-574 were upregulated in APP/PSEN1 mice, while the miRNA-335 was downregulated. Meanwhile, a bioinformatics analysis had predicted that, in particular, miRNA-574-5p could have a direct connection with neuritin (NRN1), and, therefore, in the function of synaptic plasticity. NRN1 is a neurotrophic factor involved in synaptic plasticity and neuritogenesis, which can play important roles in regeneration and repair following compromised nervous systems $[108,109]$. In order to observe the connection between synaptic loss and miRNA-574, the primary hippocampal neuron from the APP/PSEN1 transgenic mice was treated with the peptide fragment $A \beta_{25-35}$. The results revealed a high expression of miRNA-574-5p demonstrating that the $A \beta_{25-35}$ peptide could overregulate miRNA-574 expression. Successively, in order to test if miRNA-574-5p could influence the expression NRN1, HT22 hippocampal neuronal cells were transfected with miRNA-574-5p or miRNA-574-5p inhibitors. The results of the in vitro studies showed that miRNA-574 overexpression reduced the expression levels of the NRN1 protein. Conversely, NRN1 protein expression levels were significantly increased by transfecting cells with miRNA-574 inhibitors. All these data confirm the hypothesis that miRNA-574 targeting NRN1 may be directly responsible for the loss of synapses in the hippocampus of 5-month APP/PSEN1 mice.

Another miRNA that can contribute to the initiation and progression of AD is miRNA-222. In particular, the study conducted by Wang et al. [110] aimed at clarifying the interactions existing between miRNA-222 and P27 $7^{\mathrm{KIP} 1}$ in AD. P27 ${ }^{\mathrm{KIP} 1}$ is also called cyclin-dependent kinase 1B inhibitor and is responsible for blocking the cell cycle [111]. In addition, it appears that the overexpression of P27 ${ }^{\mathrm{KIP} 1}$ is correlated with the pathogenesis of AD [112]. The in vivo study conducted on APP/PSEN1 mice showed that miRNA-222 levels were downregulated compared to control. In contrast, P27 KIP1 protein levels were increased. In order to further determine whether miRNA-222 can directly regulate P27 ${ }^{\mathrm{KIP} 1}$, the researchers also analyzed changes in the level of P27 ${ }^{\mathrm{KIP} 1}$ in SH-SY5Y cells transfected with miRNA-222. Even in vitro results also confirmed an inverse correlation between the expression levels of P27 ${ }^{\mathrm{KIP} 1}$ and miRNA-222. These results show how the downregulated expression of miRNA-222 influences cell cycle dysregulation in $\mathrm{AD}$, by targeting P27 ${ }^{\mathrm{KIP}}$. 
miRNA-128 is another miRNA involved in the development and progression of AD. The downregulation of miRNA-128 seems to facilitate the degradation of $A \beta_{1-42}$, suggesting the link between miRNA-128 and AD progression [113]. The study conducted by Liu et al. [114] aimed to study the roles and molecular mechanisms of miRNA-128 in the development and progression of $\mathrm{AD}$. In the present study, it was shown that in the cerebral cortex of 3xTg-AD mice, the levels of miRNA-128 and $A \beta$ was significantly increased compared to wild type mice. On the contrary, the proliferator-activated gamma receptor (PPAR $\gamma$ ) level was downregulated. PPAR $\gamma$ plays crucial roles in multiple biological processes such as metabolism, morphogenesis, and inflammation and appears to be multiplied in the development of some neurodegenerative disorders including AD [115]. Furthermore, a large number of trials have shown that PPAR $\gamma$ agonists can improve the pathological condition of $\mathrm{AD}$ as they induce anti-inflammatory and anti-amyloidogenic effects $[116,117]$. In parallel, the researchers conducted an in vitro study, transfecting Neuro2A cells with miRNA-128 or miRNA-128 inhibitor. Even the results in vitro showed that miRNA-128 overexpression led to a marked reduction in the level of PPAR $\gamma$ protection in cells. In contrast, the PPAR $\gamma$ protein level was significantly increased in cells in which miRNA-128 was inhibited. Subsequently, 3xTg-AD mice with miRNA-128 knockout were used to further explore the roles and molecular mechanisms of miRNA-128 in AD development. The miRNA-128 level was notably reduced in the cerebral cortex of $3 \times \mathrm{Tg}$-AD mice with a miRNA-128 knockout as compared to that in the cerebral cortex of $3 \times \mathrm{Tg}$-AD mice. These mice with miRNA-128 showed improvement in cognitive abilities and reduced anxiety compared to $3 \times \mathrm{Tg}-\mathrm{AD}$ mice corresponding to age. Furthermore, the formation of amyloid plaques and the generation of $A \beta$ peptides were inhibited by inactivation of the APP amyloidogenic processing pathway. Therefore, miRNA-128 could exert its pathogenic activity by focusing on PPAR $\gamma$; on the contrary, the inhibition of $\operatorname{PPAR} \gamma$ could represent a possible therapeutic strategy.

The preclinical studies regarding the role of miRNAs in AD are summarized in Table 1. 
Table 1. A summary of microRNAs (miRNAs) linked to Alzheimer's disease (AD).

\begin{tabular}{|c|c|c|c|c|c|}
\hline miRNAs & Target mRNA & Models & Experimental Outcomes & Field of Application & Ref. \\
\hline miRNA-101a-3p & $\mathrm{APP}$ & $\begin{array}{l}\text { APP/ PSEN1 AD mice and } \\
\text { SH-SY5Y cells }\end{array}$ & $\begin{array}{l}\text { The overexpression of osthole-induced } \\
\text { miRNA inhibits APP mRNA-101a-3p and } \\
\text { reduces APP protein levels. }\end{array}$ & Therapeutic target & [40] \\
\hline miRNA-200b/c & APP & $\begin{array}{c}\text { Tg2576 mice; PMNCs and } \\
\text { SH-SY5Y cells }\end{array}$ & $\begin{array}{l}\text { miRNA-200b/c reduces } A \beta \text { secretion and } \\
\text { A } \beta \text {-induced cognitive impairment. In } \\
\text { addition, the transient transfection of } \\
\text { neurons with miRNA- } 200 \mathrm{~b} / \mathrm{c} \text {, decreased the } \\
\text { secretion of } A \beta \text { in the conditioned medium. }\end{array}$ & Therapeutic targets & [43] \\
\hline $\begin{array}{l}\text { miRNA-200b; } \\
\text { miRNA135a }\end{array}$ & APP; BACE1 & $\begin{array}{l}\text { APP/PSEN1 mice; primary } \\
\text { neurons of the hippocampus } \\
\text { mice, SH-SY5Y and } \\
\text { HEK293 cells }\end{array}$ & $\begin{array}{l}\text { miRNA-200b and miRNA-135a } \\
\text { downregulated in hippocampi from } \\
\text { APP/PS1 transgenic mice and repressed } \\
\text { respectively the expression and activity of } \\
\text { APP and BACE1. }\end{array}$ & Diagnostic markers & [44] \\
\hline miRNA200a-3p & SIRT1 & $\begin{array}{l}\text { APP/PSEN1 AD mice and } \\
\text { PC12 cells }\end{array}$ & $\begin{array}{l}\text { Increased level of the miRNA-200a-3p and } \\
\text { decreased level of SIRT1 in the hippocampus } \\
\text { of APP/PS1 mice were observed. } \\
\text { Downregulation of miRNA-200a-3p } \\
\text { protected PC12 cells from A } \beta_{25-35} \text {-induced } \\
\text { neurotoxicity and inhibited the cell } \\
\text { apoptosis. Moreover, SIRT1 was a target } \\
\text { gene of miRNA-200a-3p and exerted a } \\
\text { neuroprotective effect against } \\
\text { A } \beta_{25-35} \text {-induced toxicity in PC12 cell. }\end{array}$ & Therapeutic target & [45] \\
\hline miRNA-29c & BACE1 & $\begin{array}{l}\text { SAMP8 and SAMR1 mice, } \\
\text { primary hippocampal } \\
\text { neurons of SAMR1 mice and } \\
\text { peripheral blood of patients } \\
\text { with AD }\end{array}$ & $\begin{array}{l}\text { A decrease in miRNA-29c expression levels } \\
\text { and a significant increase in BACE1 } \\
\text { expression in peripheral blood samples from } \\
\text { AD patients were recorded. miRNA-29c } \\
\text { regulates BACE1 expression at the } \\
\text { transcriptional level by directly targeting its } \\
\text { 3'UTR. In SAMP8 mice miRNA-29c } \\
\text { promoted a decrease in the production of A } \beta \\
\text { by targeting BACE1. }\end{array}$ & Therapeutic target & [49] \\
\hline
\end{tabular}


Table 1. Cont.

\begin{tabular}{|c|c|c|c|c|c|}
\hline miRNAs & Target mRNA & Models & Experimental Outcomes & Field of Application & Ref. \\
\hline miRNA-29c & NAV3 & $\begin{array}{l}\text { APP/PSEN1 AD mice and } \\
\text { Neuro2A cells }\end{array}$ & $\begin{array}{l}\text { miRNA-29c was significantly increased in } \\
\text { the hippocampus of APP/PS1 mice, while it } \\
\text { decreased in the frontal cortex. The } \\
\text { differential expression of miRNA-29c in the } \\
\text { hippocampus and frontal cortex of the } \\
\text { APP/PS1 mouse brain was also accompanied } \\
\text { by the inverse expression of the NAV3. In } \\
\text { the in vitro study miRNA-29c directly } \\
\text { mediated downregulation of NAV3 protein } \\
\text { expression. miRNA-29c may influence } \\
\text { neurodegenerative processes by } \\
\text { targeting NAV3. }\end{array}$ & Therapeutic target & {$[50]$} \\
\hline miRNA-137 & CACNA1C & $\begin{array}{l}\text { APP/PSEN1 AD mice and } \\
\text { SH-SY5Y cells }\end{array}$ & $\begin{array}{l}\text { The level of miRNA-137 decreased, while the } \\
\text { level of CACNA1C increased in the } \\
\text { hippocampus and cerebral cortex of AD } \\
\text { mice. In SH-SY5Y cells inhibition of } \\
\text { miRNA-137 also caused an increase in } \\
\text { Ab1-42-induced hyperphosphorylation of } \\
\text { TAU in SH-SY5Y cells. }\end{array}$ & $\begin{array}{l}\text { Therapeutic target or } \\
\text { diagnostic marker }\end{array}$ & [52] \\
\hline $\begin{array}{c}\text { miRNA-10a-5p, } \\
\text { miRNA-142a-5p, } \\
\text { miRNA-146a-5p, } \\
\text { miRNA-155-5p, } \\
\text { miRNA-211- 5p and } \\
\text { miRNA-455-5p }\end{array}$ & - & APPtg and TAUtg mice & $\begin{array}{l}\text { Upregulation between APPtg and TAUtg } \\
\text { mice of miRNA-10a-5p, miRNA-142a-5p, } \\
\text { miRNA-146a-5p, miRNA-155-5p, } \\
\text { miRNA-211-5p, miRNA-455-5p; and } \\
\text { upregulation of four of these } \\
\text { (miRNA-142a-5p, miRNA-146a-5p, } \\
\text { miRNA-155-5p, and miRNA-455-5p) also in } \\
\text { AD patients. }\end{array}$ & Diagnostic markers & [57] \\
\hline miRNA-330 & VAV1 & $\begin{array}{l}\text { C57BL/6J AD mice and } \\
\text { primary neuronal cells }\end{array}$ & $\begin{array}{l}\text { Overexpression of miRNA- } 330 \text { decreases } \\
\text { expression of VAV } 1 \text { via the MAPK pathway, } \\
\text { reducing A } \beta \text { production, alleviates oxidative } \\
\text { stress and mitochondrial dysfunction. }\end{array}$ & Therapeutic target & {$[58]$} \\
\hline
\end{tabular}


Table 1. Cont.

\begin{tabular}{|c|c|c|c|c|c|}
\hline miRNAs & Target mRNA & Models & Experimental Outcomes & Field of Application & Ref. \\
\hline miRNA-34a & GRM7 & 3xTg-AD mice & $\begin{array}{c}\text { Upregulated expression of miRNA-34a } \\
\text { could be attributed to anxiety-like behaviors } \\
\text { in 3xTg-Ad mice and linked to the } \\
\text { downregulation of anxiety-related target } \\
\text { gene GRM7. }\end{array}$ & Diagnostic markers & [68] \\
\hline miRNA-34a & - & $\begin{array}{l}\text { APP/PSEN1 and miRNA-34a } \\
\text { KO/APP/PS1 mice }\end{array}$ & $\begin{array}{l}\text { The level of miRNA-34a was increased, } \\
\text { according to the increase in amyloid } \beta(\mathrm{A} \beta) \\
\text { in APP/PS1 mice; instead, in miRNA-34a } \\
\text { knockout mice, a significantly reduced } \\
\text { behavioral dysfunction was observed, } \\
\text { mainly by inhibiting the } \gamma \text {-secretase activity. }\end{array}$ & Diagnostic markers & [63] \\
\hline miRNA-34a & AMPA and NMDA & $\begin{array}{l}\text { APP/PSEN1 and miRNA-34a } \\
\text { KO/APP/PS1 mice }\end{array}$ & $\begin{array}{l}\text { miRNA-34a deficiency promotes cognitive } \\
\text { function by increasing synaptic plasticity via } \\
\text { AMPA and NMDA receptors. }\end{array}$ & Diagnostic markers & [64] \\
\hline miRNA-302/367 & - & C57BL/6J AD mice & $\begin{array}{c}\text { The miRNA-302/367 overexpression allows } \\
\text { activated astrocytes to be converted into } \\
\text { neurons by restoring some aspects of } \\
\text { learning and memory deficits in an animal } \\
\text { model of AD. }\end{array}$ & Therapeutic target & [71] \\
\hline $\begin{array}{l}\text { miRNA-125b, } \\
\text { miRNA-181c, } \\
\text { miRNA-9 and } \\
\text { miRNA-191-5p }\end{array}$ & - & $\begin{array}{c}\text { APP/PSEN1 AD mice and } \\
\text { SH-SY5Y }\end{array}$ & $\begin{array}{l}\text { Serum miRNA-125b, miRNA-191-5p, } \\
\text { miRNA-9 were significantly downregulated } \\
\text { and miRNA-28-3p was upregulated in } \\
\text { APP/PS1 transgenic mice. Instead, the level } \\
\text { of serum miRNA-125b, miRNA-9, and } \\
\text { miRNA191-5p were upregulated in } \\
\text { EGCG-treated APP/PS1. }\end{array}$ & Diagnostic markers & {$[74]$} \\
\hline
\end{tabular}


Table 1. Cont

\begin{tabular}{|c|c|c|c|c|c|}
\hline miRNAs & Target mRNA & Models & Experimental Outcomes & Field of Application & Ref. \\
\hline miRNA-139 & CB2 & SAMP8 and SAMR1 mice & $\begin{array}{l}\text { miRNA139 expression was significantly } \\
\text { higher in SAMP8 mice, compromising } \\
\text { hippocampal-dependent learning and } \\
\text { memory formation. In contrast, the } \\
\text { downregulation of miRNA-139 in mice } \\
\text { improved learning and memory in mice. } \\
\text { Furthermore, miRNA-139, by inhibiting CB2 } \\
\text { expression, decreases responses to } \\
\text { pro-inflammatory stimuli and acts as a } \\
\text { regulatory factor in the pathogenesis of AD. }\end{array}$ & Therapeutic target & {$[78]$} \\
\hline miRNA-188-5p & - & $\begin{array}{l}\text { 5xFAD mice AD model, } \\
\text { primary hippocampal neuron } \\
\text { cells and human AD brains }\end{array}$ & $\begin{array}{l}\text { The expression of miRNA-188-5p was } \\
\text { downregulated in brain tissues from patients } \\
\text { with AD and } 5 \text { XFAD mice. Treatment with } \\
\text { oligomeric } A \beta_{1-42} \text { decreased miRNA-188-5p } \\
\text { expression in primary cultures of } \\
\text { hippocampal neurons. On the contrary, } \\
\text { miRNA-188-5p overexpression could } \\
\text { alleviate the decrease in dendritic spine } \\
\text { density in primary hippocampal neurons } \\
\text { exposed to A } \beta \text {. Therefore, replenishment of } \\
\text { mi-R188-5p restores the synaptic and } \\
\text { cognitive deficits. }\end{array}$ & $\begin{array}{l}\text { Diagnostic marker and } \\
\text { therapeutic target }\end{array}$ & {$[82]$} \\
\hline miRNA-132 & ITPKB & APP/PSEN1 AD mice & $\begin{array}{l}\text { MiRNA-132 loss aggravates amyloid and } \\
\text { TAU pathology in AD brain via ITPKB } \\
\text { upregulation in AD mice model. This lead to } \\
\text { increased ERK1/2 and BACE1 activity and } \\
\text { elevated TAU phosphorylation. } \\
\text { Downregulation of miRNA132 and } \\
\text { upregulation of ITPKB was confirmed in } \\
\text { human AD patients. }\end{array}$ & $\begin{array}{l}\text { Diagnostic marker and } \\
\text { therapeutic target }\end{array}$ & [85] \\
\hline
\end{tabular}


Table 1. Cont.

\begin{tabular}{|c|c|c|c|c|c|}
\hline miRNAs & Target mRNA & Models & Experimental Outcomes & Field of Application & Ref \\
\hline miRNA-132/212 & TAU & $\begin{array}{l}\text { 3xTG-AD mice and mouse } \\
\text { Neuro2a cells }\end{array}$ & $\begin{array}{l}\text { Deletion of miRNA-132/212 caused } \\
\text { abnormal TAU metabolism, accentuate TAU } \\
\text { hyperphosphorylation and TAU aggregation. } \\
\text { TAU is a direct target of miRNA-132. On the } \\
\text { contrary, the treatment of } 3 \times T g-A D \text { mice } \\
\text { with miRNA-132 mimics improved a } \\
\text { long-term memory deficit and was } \\
\text { determinate a significant reduction of } \\
\text { phosphorylated TAU. }\end{array}$ & Therapeutic target & {$[88]$} \\
\hline miRNA-132/212 & SIRT1 & $\begin{array}{l}\text { 3xTG-AD mice and mouse } \\
\text { Neuro2a cells }\end{array}$ & $\begin{array}{c}\text { Genetic deletion of miRNA-132/212 } \\
\text { promotes A } \beta \text { production and amyloid } \\
\text { plaque formation. SIRT1, MAPK1 / ERK2, } \\
\text { and TAU were interesting miRNA-132 } \\
\text { targets identified that were found to be } \\
\text { upregulated in 3xTg-AD mice compared to } \\
\text { controls. In contrast, all these genes were } \\
\text { downregulated in Neuro2a132 cells. In } \\
\text { addition, the modulation of miRNA-132 or } \\
\text { SIRT1 can directly regulate A } \beta \text { production } \\
\text { in cells. }\end{array}$ & Therapeutic target & [91] \\
\hline miRNA-181 & SIRT1 and c-Fos & $\begin{array}{l}\text { 3xTG-AD mice and } \\
\text { SH-SY5Y cells }\end{array}$ & $\begin{array}{l}\text { Compared to twelve-month wild type mice } \\
\text { in the hippocampus of age-matched } \\
\text { 3xTg-AD mice with plaques and tangles was } \\
\text { found a significant upregulation of } \\
\text { miRNA-181. Analysis of predicted targets of } \\
\text { miRNA-181 identified c-Fos and SIRT-1. } \\
\text { Both c-Fos and SIRT-1 levels were } \\
\text { significantly decreased in the ventral } \\
\text { hippocampus of twelve-month old 3xTg-AD } \\
\text { mice. In addition, overexpression of } \\
\text { miRNA-181 in SH-SY5Y cells significantly } \\
\text { decreased c-Fos and SIRT-1. }\end{array}$ & $\begin{array}{l}\text { Diagnostic marker and } \\
\text { therapeutic target }\end{array}$ & {$[94]$} \\
\hline
\end{tabular}


Table 1. Cont.

\begin{tabular}{|c|c|c|c|c|c|}
\hline miRNAs & Target mRNA & Models & Experimental Outcomes & Field of Application & Ref. \\
\hline miRNA-181c & CRMP-2 & $\begin{array}{l}\text { SAMP8 and SAMR1 mice; } \\
\text { HT-22 and HEK293A cells }\end{array}$ & $\begin{array}{l}\text { A significant decrease in miRNA-181c in the } \\
\text { hippocampus of SAMP8 was recorded. } \\
\text { miRNA-181c overexpression affects the 3'-UTR } \\
\text { region of CRMP2. In HT-22 hippocampal } \\
\text { neuronal cells, the overexpression of } \\
\text { miRNA-181c downregulates the abundance of } \\
\text { CRMP2 proteins at the } \\
\text { post-transcriptional level. }\end{array}$ & Diagnostic marker & [96] \\
\hline miRNA-206 & BDNF & $\begin{array}{l}\text { APP/PSEN1 mice and } \\
\text { primary neuron cells from } \\
\text { embryonic } \\
\text { APP/PSEN1 mice } \\
\text { hippocampus }\end{array}$ & $\begin{array}{c}\text { miRNA-206 was upregulated, this } \\
\text { overexpression resulted in a downregulated } \\
\text { expression of BDNF that protects against } \\
\text { cell death. }\end{array}$ & Diagnostic marker & [99] \\
\hline miRNA-214-3p & ATG12 & $\begin{array}{l}\text { SAMR1 and SAMP8 mice; } \\
\text { primary neuron cells from } \\
\text { embryonic } \\
\text { SAMP8 mice hippocampus } \\
\text { and SH-SY5Y cells }\end{array}$ & $\begin{array}{l}\text { Downregulated miRNA-214-3p was observed } \\
\text { in hippocampal neurons of SAMP8 mice and } \\
\text { also in cerebrospinal fluid from patients with } \\
\text { SAD. miRNA-214-3p overexpression in } \\
\text { primary neurons from SAMP8 mice inhibited } \\
\text { autophagy. In contrast, antagomiRNA-214-3p } \\
\text { promoted macroautophagy and apoptosis in } \\
\text { SAMP8 mice neurons. miRNA-214-3p by } \\
\text { directly targeting ATG12 inhibits the } \\
\text { macroautophagy. In addition, the injection of } \\
\text { miRNA-214-3p into the hippocampal } \\
\text { improved the cognitive capacity of } \\
\text { SAMP8 mice. }\end{array}$ & Therapeutic target & [106] \\
\hline miRNA-146-a & ROCK1 & $\begin{array}{l}\text { 5xFAD mice and } \\
\text { SH-SY5Y cells }\end{array}$ & $\begin{array}{l}\text { High levels of miRNANA-146a in neurons } \\
\text { negatively regulate the translation of the } \\
\text { ROCK1 protein. Reduction of neuronal protein } \\
\text { ROCK1 leads to a reduction in the neuronal } \\
\text { phosphorylation of PTEN resulting in the } \\
\text { impaired dephosphorylation of neuronal TAU. }\end{array}$ & $\begin{array}{l}\text { Diagnostic marker and } \\
\text { therapeutic target }\end{array}$ & [92] \\
\hline
\end{tabular}


Table 1. Cont.

\begin{tabular}{|c|c|c|c|c|c|}
\hline miRNAs & Target mRNA & Models & Experimental Outcomes & Field of Application & Ref. \\
\hline miRNA-574 & NRN1 & $\begin{array}{l}\text { APP/PSEN1 mice; primary } \\
\text { hippocampal neuron from the } \\
\text { wild type and APP/PS1 } \\
\text { transgenic mice and HT22 } \\
\text { hippocampal neuronal cells }\end{array}$ & $\begin{array}{l}\text { miRNA- } 574 \text { was significantly increased in } \\
\text { the hippocampus of } 5 \text {-month APP/PS1 mice, } \\
\text { showing synaptic loss and cognitive } \\
\text { impairment. Bioinformatic analysis } \\
\text { predicted that mRNA- } 574 \text { targets the mRNA } \\
\text { of Nrn1. In fact, in the in vitro study, } \\
\text { miRNA-574 overexpression reduced NRN1 } \\
\text { expression levels. In contrast, miRNA-574 } \\
\text { suppression by the miRNA-574 inhibitor } \\
\text { resulted in elevated levels of } \\
\text { NRN1 expression. }\end{array}$ & $\begin{array}{l}\text { Diagnostic marker and } \\
\text { therapeutic target }\end{array}$ & [107] \\
\hline miRNA-222 & $\mathrm{P} 27^{\mathrm{KIP} 1}$ & $\begin{array}{c}\text { APP/PSEN1 mice, SH-SY5Y } \\
\text { and HEK-293T }\end{array}$ & $\begin{array}{l}\text { Downregulation expression of miRNA-222 } \\
\text { influences cell cycle dysregulation in AD, by } \\
\text { targeting P27KIP1 }\end{array}$ & - & [110] \\
\hline miRNA-128 & $\operatorname{PPAR} \gamma$ & $\begin{array}{l}\text { 3xTG-AD mice and } \\
\text { Neuro2A cells }\end{array}$ & $\begin{array}{l}\text { The expression of miRNA- } 128 \text { was } \\
\text { upregulated, on the contrary, the expression } \\
\text { of PPAR } \gamma \text { was downregulated in the cerebral } \\
\text { cortex of AD mice. Furthermore, PPAR } \gamma \text { was } \\
\text { a target of miRNA-128. In addition, the } \\
\text { upregulation of miRNA- } 128 \text { or the } \\
\text { upregulation of PPAR } \gamma \text { inhibited type AD } \\
\text { performance, the formation of amyloid } \\
\text { plaques, the generation of A } \beta \text {, the } \\
\text { amyloidogenic processing of APP, and the } \\
\text { inflammatory responses in AD mice. Instead, } \\
\text { the inhibition of PPAR } \gamma \text { improves the effects } \\
\text { caused by miRNA- } 128 \text {. }\end{array}$ & $\begin{array}{l}\text { Diagnostic marker and } \\
\text { therapeutic target }\end{array}$ & [114] \\
\hline
\end{tabular}


Author Contributions: S.S. wrote the manuscript; P.B. revised the manuscript; and E.M. conceived and revised the manuscript.

Funding: This work was supported by Ricerca Finalizzata RF-2013-02359594 entitled “Vitamin E, miRNA and inflammation: a tunable network in Alzheimer's disease".

Acknowledgments: This manuscript was supported by grants of the Italian Ministry of Health.

Conflicts of Interest: The authors declare no conflict of interest.

\section{Abbreviations}

\begin{tabular}{|c|c|}
\hline $\mathrm{AD}$ & Alzheimer's disease \\
\hline$A \beta$ & Amyloid-beta \\
\hline NFTs & Neurofibrillary tangles \\
\hline FAD & Familial Alzheimer's disease \\
\hline SAD & Sporadic Alzheimer's disease \\
\hline $\mathrm{APP}$ & Amyloid precursor protein \\
\hline BACE1 & $\beta$-site amyloid precursor protein cleaving enzyme \\
\hline PSEN1 & Presenilin 1 \\
\hline PSEN2 & Presenilin 2 \\
\hline APOE & Apolipoprotein E \\
\hline LRP1 & Protein 1 associated with the LDL receptor \\
\hline UTR & Untranslated region \\
\hline mRNAs & Messenger RNAs \\
\hline Pri-miRNAs & Primary miRNAs \\
\hline Pre-miRNAs & Precursor miRNAs \\
\hline RISC & RNA-induced silencing complex \\
\hline SH-SY5Y & Human neuroblastoma \\
\hline PMNCs & Primary murine neuronal cells \\
\hline qRT-PCR & Quantitative reverse transcription PCR \\
\hline HEK293 & Human embryonic kidney 293 \\
\hline SIRT1 & Silent information regulator transcript- 1 \\
\hline $\mathrm{Ca}^{2+}$ & Calcium \\
\hline VAV1 & Guanine nucleotide exchange factor 1 \\
\hline MAPK & Mitogen-activated protein kinase \\
\hline $3 \times T g-A D$ & Triple transgenic mice model of AD \\
\hline GRM7 & Metabotropic glutamate receptor 7 \\
\hline miRNA-34a KO/APP/PS1 & miRNA-34a knockouts APP/PSEN1 mice \\
\hline AMPA & $\alpha$-amino-3-hydroxy-5-methyl-4-isoxazolepropionic acid \\
\hline NMDA & $N$-methyl-D-aspartate \\
\hline STZ & Streptozotocin \\
\hline VPA & Valproate \\
\hline EGCG & Epigallocatechin gallate \\
\hline SAMP8 & Senescence-accelerated mouse prone 8 \\
\hline SAMR1 & Senescence-accelerated mouse-resistant 1 \\
\hline CB2 & Cannabinoid receptor type 2 \\
\hline ITPKB & Inositol 1,4,5-trisphosphate 3-kinase B \\
\hline Neuro2a & Neuroblastoma 2a \\
\hline Neuro2a132 & Neuro2a cells treated with miRNA-132 mimics \\
\hline Crmp2 & Collapsin response mediator protein 2 \\
\hline BDNF & Brain-derived neurotrophic factor \\
\hline ROCK1 & Coiled-coil containing protein kinase 1 \\
\hline PTEN & Phosphatase and tensin homolog \\
\hline NAV3 & Navigator neuron 3 \\
\hline Nrn1 & Neuritin \\
\hline PPAR $\gamma$ & Proliferator-activated receptor gamma \\
\hline
\end{tabular}




\section{References}

1. Lane, C.A.; Hardy, J.; Schott, J.M. Alzheimer's disease. Eur. J. Neurol. 2018, 25, 59-70. [CrossRef] [PubMed]

2. Buono, V.L.; Bonanno, L.; Corallo, F.; Foti, M.; Palmeri, R.; Angela, M.; Di Lorenzo, G.; Todaro, A.; Bramanti, P.; Bramanti, A. Qualitative Analysis of Mini Mental State Examination Pentagon in Vascular Dementia and Alzheimer's disease: A Longitudinal Explorative Study. J. Stroke Cerebrovasc. Dis. 2018, 27, 1666-1672. [CrossRef] [PubMed]

3. Allone, C.; Lo Buono, V.; Corallo, F.; Bonanno, L.; Palmeri, R.; Di Lorenzo, G.; Marra, A.; Bramanti, P.; Marino, S. Cognitive impairment in Parkinson's disease, Alzheimer's dementia, and vascular dementia: The role of the clock-drawing test. Psychogeriatrics 2018, 18, 123-131. [CrossRef] [PubMed]

4. Marra, A.; Naro, A.; Chillura, A.; Bramanti, A.; Maresca, G.; De Luca, R.; Manuli, A.; Bramanti, P.; Calabrò, R.S. Evaluating Peripersonal Space through the Functional Transcranial Doppler: Are We Paving the Way for Early Detecting Mild Cognitive Impairment to Dementia Conversion? J. Alzheimer's Dis. 2018, 62, 133-143. [CrossRef] [PubMed]

5. Hardy, J.A.; Higgins, G.A. Alzheimer's disease: The amyloid cascade hypothesis. Science 1992, 256, $184-186$. [CrossRef]

6. Müller, U.C.; Deller, T.; Korte, M. Not just amyloid: Physiological functions of the amyloid precursor protein family. Nat. Rev. Neurosci. 2017, 18, 281. [CrossRef]

7. Gupta, A.; Goyal, R. Amyloid beta plaque: A culprit for neurodegeneration. Acta. Neurol. Belg. 2016, 116, 445-450. [CrossRef]

8. Zhang, Y.-W.; Thompson, R.; Zhang, H.; Xu, H. APP processing in Alzheimer's disease. Mol. Brain 2011, 4, 3. [CrossRef]

9. Doran, E.; Keator, D.; Head, E.; Phelan, M.J.; Kim, R.; Totoiu, M.; Barrio, J.R.; Small, G.W.; Potkin, S.G.; Lott, I.T. Down syndrome, partial trisomy 21, and absence of Alzheimer's disease: The role of APP. J. Alzheimer's Dis. 2017, 56, 459-470. [CrossRef]

10. Parsons, R.; Austen, B. Protein-protein interactions in the assembly and subcellular trafficking of the BACE ( $\beta$-site amyloid precursor protein-cleaving enzyme) complex of Alzheimer's disease. Biochem. Soc. Trans. 2007, 35, 974-979. [CrossRef]

11. Querfurth, H.W.; LaFerla, F.M. Mechanisms of disease. N. Engl. J. Med. 2010, 362, 329-344. [CrossRef] [PubMed]

12. Zhang, H.; Ma, Q.; Zhang, Y.w.; Xu, H. Proteolytic processing of Alzheimer's $\beta$-amyloid precursor protein. J. Neurochem. Rev. 2012, 120, 9-21. [CrossRef] [PubMed]

13. Näslund, J.; Haroutunian, V.; Mohs, R.; Davis, K.L.; Davies, P.; Greengard, P.; Buxbaum, J.D. Correlation between elevated levels of amyloid $\beta$-peptide in the brain and cognitive decline. JAMA 2000, 283, 1571-1577. [CrossRef] [PubMed]

14. Mammana, S.; Fagone, P.; Cavalli, E.; Basile, M.; Petralia, M.; Nicoletti, F.; Bramanti, P.; Mazzon, E. The role of macrophages in neuroinflammatory and neurodegenerative pathways of alzheimer's disease, amyotrophic lateral sclerosis, and multiple sclerosis: Pathogenetic cellular effectors and potential therapeutic targets. Int. J. Mol. Sci. 2018, 19, 831. [CrossRef] [PubMed]

15. Libro, R.; Bramanti, P.; Mazzon, E. Endogenous glucocorticoids: Role in the etiopathogenesis of Alzheimer's disease. Neuroendocrinol. Lett. 2017, 38, 1-12. [PubMed]

16. Lindwall, G.; Cole, R.D. Phosphorylation affects the ability of tau protein to promote microtubule assembly. J. Biol. Chem. 1984, 259, 5301-5305. [PubMed]

17. Iqbal, K.; Alonso, A.d.C.; Chen, S.; Chohan, M.O.; El-Akkad, E.; Gong, C.-X.; Khatoon, S.; Li, B.; Liu, F.; Rahman, A. Tau pathology in Alzheimer disease and other tauopathies. Biochim. Biophys. Acta (BBA)-Mol. Basis Dis. 2005, 1739, 198-210. [CrossRef]

18. Ballard, C.G.; Waite, J.; Birks, J. Atypical antipsychotics for aggression and psychosis in Alzheimer's disease. Cochrane Database Syst. Rev. 2006, 1, CD003476. [CrossRef]

19. Giri, M.; Zhang, M.; Lü, Y. Genes associated with Alzheimer's disease: An overview and current status. Clin. Interv. Aging 2016, 11, 665. [CrossRef]

20. Piaceri, I.; Nacmias, B.; Sorbi, S. Genetics of familial and sporadic Alzheimer's disease. Front. Biosci. 2013, 5, 167-177. [CrossRef] 
21. Campion, D.; Dumanchin, C.; Hannequin, D.; Dubois, B.; Belliard, S.; Puel, M.; Thomas-Anterion, C.; Michon, A.; Martin, C.; Charbonnier, F. Early-onset autosomal dominant Alzheimer disease: Prevalence, genetic heterogeneity, and mutation spectrum. Am. J. Hum. Genet. 1999, 65, 664-670. [CrossRef] [PubMed]

22. Kim, J.; Basak, J.M.; Holtzman, D.M. The role of apolipoprotein E in Alzheimer's disease. Neuron 2009, 63, 287-303. [CrossRef] [PubMed]

23. Phillips, C. Lifestyle modulators of neuroplasticity: How physical activity, mental engagement, and diet promote cognitive health during aging. Neural Plast. 2017, 2017, 3589271. [CrossRef] [PubMed]

24. Gugliandolo, A.; Bramanti, P.; Mazzon, E. Role of vitamin E in the treatment of Alzheimer's disease: Evidence from animal models. Int. J. Mol. Sci. 2017, 18, 2504. [CrossRef] [PubMed]

25. Giacoppo, S.; Soundara Rajan, T.; Bramanti, P.; Mazzon, E. Natural phytochemicals in the treatment and prevention of dementia: An overview. Molecules 2016, 21, 518.

26. Provost, P. Interpretation and applicability of microRNA data to the context of Alzheimer's and age-related diseases. Aging 2010, 2, 166. [CrossRef] [PubMed]

27. Lukiw, W.J. Micro-RNA speciation in fetal, adult and Alzheimer's disease hippocampus. Neuroreport 2007, 18, 297-300. [CrossRef]

28. Guedes, J.R.; Santana, I.; Cunha, C.; Duro, D.; Almeida, M.R.; Cardoso, A.M.; de Lima, M.C.; Cardoso, A.L. MicroRNA deregulation and chemotaxis and phagocytosis impairment in Alzheimer's disease. Alzheimer's Dement 2016, 3, 7. [CrossRef]

29. Angelucci, F. Micro RNAs in Alzheimer's disease: Diagnostic markers or therapeutic agents? Front. Pharmacol. 2019, 10, 665. [CrossRef]

30. DeVos, S.L.; Miller, T.M. Direct intraventricular delivery of drugs to the rodent central nervous system. JoVE (J. Vis. Exp.) 2013, 75, e50326. [CrossRef]

31. Bartel, D.P. MicroRNAs: Genomics, biogenesis, mechanism, and function. Cell 2004, 116, 281-297. [CrossRef]

32. Vishnoi, A.; Rani, S. MiRNA biogenesis and regulation of diseases: An overview. In MicroRNA Profiling; Springer Humana Press: New York, NY, USA, 2017; pp. 1-10.

33. Lee, Y.; Jeon, K.; Lee, J.T.; Kim, S.; Kim, V.N. MicroRNA maturation: Stepwise processing and subcellular localization. EMBO J. 2002, 21, 4663-4670. [CrossRef] [PubMed]

34. Yi, R.; Qin, Y.; Macara, I.G.; Cullen, B.R. Exportin-5 mediates the nuclear export of pre-microRNAs and short hairpin RNAs. Genes Dev. 2003, 17, 3011-3016. [CrossRef] [PubMed]

35. Lund, E.; Güttinger, S.; Calado, A.; Dahlberg, J.E.; Kutay, U. Nuclear export of microRNA precursors. Science 2004, 303, 95-98. [CrossRef] [PubMed]

36. Diederichs, S.; Haber, D.A. Dual role for argonautes in microRNA processing and posttranscriptional regulation of microRNA expression. Cell 2007, 131, 1097-1108. [CrossRef]

37. Valencia-Sanchez, M.A.; Liu, J.; Hannon, G.J.; Parker, R. Control of translation and mRNA degradation by miRNAs and siRNAs. Genes Dev. 2006, 20, 515-524. [CrossRef] [PubMed]

38. Reddy, P.H.; Tonk, S.; Kumar, S.; Vijayan, M.; Kandimalla, R.; Kuruva, C.S.; Reddy, A.P. A critical evaluation of neuroprotective and neurodegenerative MicroRNAs in Alzheimer's disease. Biochem. Biophys. Res. Commun. 2017, 483, 1156-1165. [CrossRef]

39. Schratt, G. microRNAs at the synapse. Nat. Rev. Neurosci. 2009, 10, 842. [CrossRef]

40. Lin, Y.; Liang, X.; Yao, Y.; Xiao, H.; Shi, Y.; Yang, J. Osthole attenuates APP-induced Alzheimer's disease through up-regulating miRNA-101a-3p. Life Sci. 2019, 225, 117-131. [CrossRef]

41. Campos-Esparza, M.R.; Sanchez-Gomez, M.V.; Matute, C. Molecular mechanisms of neuroprotection by two natural antioxidant polyphenols. Cell Calcium 2009, 45, 358-368. [CrossRef]

42. Dong, X.; Zhang, D.; Zhang, L.; Li, W.; Meng, X. Osthole improves synaptic plasticity in the hippocampus and cognitive function of Alzheimer's disease rats via regulating glutamate. Neural Regen. Res. 2012, 7, 2325. [PubMed]

43. Higaki, S.; Muramatsu, M.; Matsuda, A.; Matsumoto, K.; Satoh, J.-i.; Michikawa, M.; Niida, S. Defensive effect of microRNA-200b/c against amyloid-beta peptide-induced toxicity in Alzheimer's disease models. PLoS ONE 2018, 13, e0196929. [CrossRef] [PubMed]

44. Liu, C.-g.; Wang, J.-1.; Li, L.; Xue, L.-x.; Zhang, Y.-q.; Wang, P.-c. MicroRNA-135a and-200b, potential Biomarkers for Alzheimer's disease, regulate $\beta$ secretase and amyloid precursor protein. Brain Res. 2014, 1583, 55-64. [CrossRef] [PubMed] 
45. Zhang, Q.-S.; Liu, W.; Lu, G.-X. miR-200a-3p promotes $\beta$-Amyloid-induced neuronal apoptosis through down-regulation of SIRT1 in Alzheimer's disease. J. Biosci. 2017, 42, 397-404. [CrossRef] [PubMed]

46. Marwarha, G.; Raza, S.; Meiers, C.; Ghribi, O. Leptin attenuates BACE1 expression and amyloid- $\beta$ genesis via the activation of SIRT1 signaling pathway. Biochim. Biophys. Acta (BBA)-Mol. Basis Dis. 2014, 1842, 1587-1595. [CrossRef] [PubMed]

47. Donmez, G.; Outeiro, T.F. SIRT1 and SIRT2: Emerging targets in neurodegeneration. EMBO Mol. Med. 2013, 5, 344-352. [CrossRef] [PubMed]

48. Hébert, S.S.; Horré, K.; Nicolaï, L.; Papadopoulou, A.S.; Mandemakers, W.; Silahtaroglu, A.N.; Kauppinen, S.; Delacourte, A.; De Strooper, B. Loss of microRNA cluster miR-29a/b-1 in sporadic Alzheimer's disease correlates with increased BACE1/ß-secretase expression. Proc. Natl. Acad. Sci. USA 2008, 105, 6415-6420. [CrossRef]

49. Yang, G.; Song, Y.; Zhou, X.; Deng, Y.; Liu, T.; Weng, G.; Yu, D.; Pan, S. MicroRNA-29c targets $\beta$-site amyloid precursor protein-cleaving enzyme 1 and has a neuroprotective role in vitro and in vivo. Mol. Med. Rep. 2015, 12, 3081-3088. [CrossRef]

50. Zong, Y.; Yu, P.; Cheng, H.; Wang, H.; Wang, X.; Liang, C.; Zhu, H.; Qin, Y.; Qin, C. miR-29c regulates NAV3 protein expression in a transgenic mouse model of Alzheimer's disease. Brain Res. 2015, 1624, 95-102. [CrossRef]

51. Hekimi, S.; Kershaw, D. Axonal guidance defects in a Caenorhabditis elegans mutant reveal cell-extrinsic determinants of neuronal morphology. J. Neurosci. 1993, 13, 4254-4271. [CrossRef]

52. Jiang, Y.; Xu, B.; Chen, J.; Sui, Y.; Ren, L.; Li, J.; Zhang, H.; Guo, L.; Sun, X. Micro-RNA-137 Inhibits Tau Hyperphosphorylation in Alzheimer's disease and Targets the CACNA1C Gene in Transgenic Mice and Human Neuroblastoma SH-SY5Y Cells. Med. Sci. Monit. Int. Med. J. Exp. Clin. Res. 2018, 24, 5635-5644. [CrossRef] [PubMed]

53. Geekiyanage, H.; Chan, C. MicroRNA-137/181c regulates serine palmitoyltransferase and in turn amyloid $\beta$, novel targets in sporadic Alzheimer's disease. J. Neurosci. 2011, 31, 14820-14830. [CrossRef] [PubMed]

54. Geekiyanage, H.; Chan, C. SPT, miR-137 and miR-181c: Therapeutic targets and noninvasive biomarkers. Alzheimer's Dement. J. Alzheimer's Assoc. 2012, 8, 470-471. [CrossRef]

55. Jakobsson, J.; Pålsson, E.; Sellgren, C.; Rydberg, F.; Ekman, A.; Zetterberg, H.; Blennow, K.; Landen, M. CACNA1C polymorphism and altered phosphorylation of tau in bipolar disorder. Br. J. Psychiatry 2016, 208, 195-196. [CrossRef] [PubMed]

56. Davare, M.A.; Hell, J.W. Increased phosphorylation of the neuronal L-type Ca2+ channel Cav1. 2 during aging. Proc. Natl. Acad. Sci. USA 2003, 100, 16018-16023. [CrossRef] [PubMed]

57. Sierksma, A.; Lu, A.; Salta, E.; Eynden, E.V.; Callaerts-Vegh, Z.; D’hooge, R.; Blum, D.; Buée, L.; Fiers, M.; De Strooper, B. Deregulation of neuronal miRNAs induced by amyloid- $\beta$ or TAU pathology. Mol. Neurodegener. 2018, 13, 54. [CrossRef] [PubMed]

58. Zhou, Y.; Wang, Z.F.; Li, W.; Hong, H.; Chen, J.; Tian, Y.; Liu, Z.Y. Protective effects of microRNA-330 on amyloid $\beta$-protein production, oxidative stress, and mitochondrial dysfunction in Alzheimer's disease by targeting VAV1 via the MAPK signaling pathway. J. Cell. Biochem. 2018, 119, 5437-5448. [CrossRef] [PubMed]

59. Rodríguez-Fdez, S.; Bustelo, X.R. The Vav GEF Family: An Evolutionary and Functional Perspective. Cells 2019, 8, 465. [CrossRef] [PubMed]

60. Choi, I.; Woo, J.H.; Jou, I.; Joe, E.-h. PINK1 deficiency decreases expression levels of mir-326, mir-330, and mir-3099 during brain development and neural stem cell differentiation. Exp. Neurobiol. 2016, 25, 14-23. [CrossRef]

61. Kim, E.K.; Choi, E.-J. Pathological roles of MAPK signaling pathways in human diseases. Biochim. Biophys. Acta (BBA)-Mol. Basis Dis. 2010, 1802, 396-405. [CrossRef]

62. Yang, W.; Ma, K.; Chen, X.; Shi, L.; Bu, G.; Hu, X.; Han, H.; Liu, Y.; Qian, Y. Mitogen-activated protein kinase signaling pathways are involved in regulating $\alpha 7$ nicotinic acetylcholine receptor-mediated amyloid- $\beta$ uptake in SH-SY5Y cells. Neuroscience 2014, 278, 276-290. [CrossRef] [PubMed]

63. Jian, C.; Lu, M.; Zhang, Z.; Liu, L.; Li, X.; Huang, F.; Xu, N.; Qin, L.; Zhang, Q.; Zou, D. miR-34a knockout attenuates cognitive deficits in APP/PS1 mice through inhibition of the amyloidogenic processing of APP. Life Sci. 2017, 182, 104-111. [CrossRef] [PubMed] 
64. Xu, Y.; Chen, P.; Wang, X.; Yao, J.; Zhuang, S. miR-34a deficiency in APP/PS1 mice promotes cognitive function by increasing synaptic plasticity via AMPA and NMDA receptors. Neurosci. Lett. 2018, 670, 94-104. [CrossRef] [PubMed]

65. Rumpel, S.; LeDoux, J.; Zador, A.; Malinow, R. Postsynaptic receptor trafficking underlying a form of associative learning. Science 2005, 308, 83-88. [CrossRef] [PubMed]

66. Krugers, H.J.; Hoogenraad, C.C.; Groc, L. Stress hormones and AMPA receptor trafficking in synaptic plasticity and memory. Nat. Rev. Neurosci. 2010, 11, 675. [CrossRef] [PubMed]

67. Paoletti, P.; Bellone, C.; Zhou, Q. NMDA receptor subunit diversity: Impact on receptor properties, synaptic plasticity and disease. Nat. Rev. Neurosci. 2013, 14, 383. [CrossRef]

68. Zhang, Y.; Xing, R.; Luo, X.; Xu, H.; Chang, R.; Zou, L.; Liu, J.; Yang, X. Anxiety-like behavior and dysregulation of miR-34a in triple transgenic mice of Alzheimer's disease. Eur Rev. Med. Pharm. Sci. 2016, 20, 2853-2862.

69. O'Connor, R.M.; Thakker, D.R.; Schmutz, M.; van der Putten, H.; Hoyer, D.; Flor, P.J.; Cryan, J.F. Adult siRNA-induced knockdown of mGlu7 receptors reduces anxiety in the mouse. Neuropharmacology 2013, 72, 66-73. [CrossRef]

70. Leonardo, T.R.; Schultheisz, H.L.; Loring, J.F.; Laurent, L.C. The functions of microRNAs in pluripotency and reprogramming. Nat. Cell Biol. 2012, 14, 1114. [CrossRef]

71. Ghasemi-Kasman, M.; Shojaei, A.; Gol, M.; Moghadamnia, A.A.; Baharvand, H.; Javan, M. miR-302/367-induced neurons reduce behavioral impairment in an experimental model of Alzheimer's disease. Mol. Cell. Neurosci. 2018, 86, 50-57. [CrossRef]

72. Gao, Z.; Zhu, X.; Dou, Y. The miR-302/367 cluster: A comprehensive update on its evolution and functions. Open Biol. 2015, 5, 150138. [CrossRef] [PubMed]

73. Sorial, M.E.; El Sayed, N.S.E.D. Protective effect of valproic acid in streptozotocin-induced sporadic Alzheimer's disease mouse model: Possible involvement of the cholinergic system. Naunyn-Schmiedeberg's Arch. Pharmacol. 2017, 390, 581-593. [CrossRef] [PubMed]

74. Hong, H.; Li, Y.; Su, B. Identification of circulating miR-125b as a potential biomarker of Alzheimer's disease in APP/PS1 transgenic mouse. J. Alzheimer's Dis. 2017, 59, 1449-1458. [CrossRef] [PubMed]

75. Tan, L.; Yu, J.T.; Liu, Q.Y.; Tan, M.S.; Zhang, W.; Hu, N.; Wang, Y.L.; Sun, L.; Jiang, T.; Tan, L. Circulating miR-125b as a biomarker of Alzheimer's disease. J. Neurol. Sci. 2014, 336, 52-56. [CrossRef] [PubMed]

76. Unno, K.; Takabayashi, F.; Yoshida, H.; Choba, D.; Fukutomi, R.; Kikunaga, N.; Kishido, T.; Oku, N.; Hoshino, M. Daily consumption of green tea catechin delays memory regression in aged mice. Biogerontology 2007, 8, 89-95. [CrossRef]

77. Schaffer, S.; Asseburg, H.; Kuntz, S.; Muller, W.E.; Eckert, G.P. Effects of polyphenols on brain ageing and Alzheimer's disease: Focus on mitochondria. Mol. Neurobiol. 2012, 46, 161-178. [CrossRef] [PubMed]

78. Tang, Y.; Bao, J.; Su, J.; Huang, W. MicroRNA-139 modulates Alzheimer's-associated pathogenesis in SAMP8 mice by targeting cannabinoid receptor type 2. Genet. Mol. Res. 2017, 16. [CrossRef]

79. Benito, C.; Núñez, E.; Tolón, R.M.; Carrier, E.J.; Rábano, A.; Hillard, C.J.; Romero, J. Cannabinoid CB2 receptors and fatty acid amide hydrolase are selectively overexpressed in neuritic plaque-associated glia in Alzheimer's disease brains. J. Neurosci. 2003, 23, 11136-11141. [CrossRef]

80. Wu, J.; Bie, B.; Yang, H.; Xu, J.J.; Brown, D.L.; Naguib, M. Activation of the CB2 receptor system reverses amyloid-induced memory deficiency. Neurobiol. Aging 2013, 34, 791-804. [CrossRef]

81. Ehrhart, J.; Obregon, D.; Mori, T.; Hou, H.; Sun, N.; Bai, Y.; Klein, T.; Fernandez, F.; Tan, J.; Shytle, R.D. Stimulation of cannabinoid receptor 2 (CB 2) suppresses microglial activation. J. Neuroinflamm. 2005, 2, 29. [CrossRef]

82. Lee, K.; Kim, H.; An, K.; Kwon, O.-B.; Park, S.; Cha, J.H.; Kim, M.-H.; Lee, Y.; Kim, J.-H.; Cho, K. Replenishment of microRNA-188-5p restores the synaptic and cognitive deficits in 5XFAD Mouse Model of Alzheimer's Disease. Sci. Rep. 2016, 6, 34433. [CrossRef] [PubMed]

83. Lau, P.; Bossers, K.; Salta, E.; Frigerio, C.S.; Barbash, S.; Rothman, R.; Sierksma, A.S.; Thathiah, A.; Greenberg, D.; Papadopoulou, A.S. Alteration of the microRNA network during the progression of Alzheimer's disease. EMBO Mol. Med. 2013, 5, 1613-1634. [CrossRef] [PubMed]

84. Wong, H.-K.A.; Veremeyko, T.; Patel, N.; Lemere, C.A.; Walsh, D.M.; Esau, C.; Vanderburg, C.; Krichevsky, A.M. De-repression of FOXO3a death axis by microRNA-132 and-212 causes neuronal apoptosis in Alzheimer's disease. Hum. Mol. Genet. 2013, 22, 3077-3092. [CrossRef] [PubMed] 
85. Salta, E.; Sierksma, A.; Eynden, E.V.; De Strooper, B. miR-132 loss de-represses ITPKB and aggravates amyloid and TAU pathology in Alzheimer's brain. EMBO Mol. Med. 2016, 8, 1005-1018. [CrossRef] [PubMed]

86. Wen, B.G.; Pletcher, M.T.; Warashina, M.; Choe, S.H.; Ziaee, N.; Wiltshire, T.; Sauer, K.; Cooke, M.P. Inositol $(1,4,5)$ trisphosphate 3 kinase B controls positive selection of T cells and modulates Erk activity. Proc. Natl. Acad. Sci. USA 2004, 101, 5604-5609. [CrossRef] [PubMed]

87. Maréchal, Y.; Pesesse, X.; Jia, Y.; Pouillon, V.; Pérez-Morga, D.; Daniel, J.; Izui, S.; Cullen, P.J.; Leo, O.; Luo, H.R. Inositol 1, 3, 4, 5-tetrakisphosphate controls proapoptotic Bim gene expression and survival in B cells. Proc. Natl. Acad. Sci. USA 2007, 104, 13978-13983. [CrossRef] [PubMed]

88. Smith, P.Y.; Hernandez-Rapp, J.; Jolivette, F.; Lecours, C.; Bisht, K.; Goupil, C.; Dorval, V.; Parsi, S.; Morin, F.; Planel, E. miR-132/212 deficiency impairs tau metabolism and promotes pathological aggregation in vivo. Hum. Mol. Genet. 2015, 24, 6721-6735. [CrossRef]

89. Hernandez-Rapp, J.; Smith, P.Y.; Filali, M.; Goupil, C.; Planel, E.; Magill, S.T.; Goodman, R.H.; Hébert, S.S. Memory formation and retention are affected in adult miR-132/212 knockout mice. Behav. Brain Res. 2015, 287, 15-26. [CrossRef]

90. Ambegaokar, S.S.; Jackson, G.R. The downward spiral of tau and autolysosomes: A new hypothesis in neurodegeneration. Autophagy 2012, 8, 1144-1145. [CrossRef]

91. Hernandez-Rapp, J.; Rainone, S.; Goupil, C.; Dorval, V.; Smith, P.Y.; Saint-Pierre, M.; Vallée, M.; Planel, E.; Droit, A.; Calon, F. microRNA-132/212 deficiency enhances A $\beta$ production and senile plaque deposition in Alzheimer's disease triple transgenic mice. Sci. Rep. 2016, 6, 30953. [CrossRef]

92. Wang, G.; Huang, Y.; Wang, L.-L.; Zhang, Y.-F.; Xu, J.; Zhou, Y.; Lourenco, G.F.; Zhang, B.; Wang, Y.; Ren, R.-J. MicroRNA-146a suppresses ROCK1 allowing hyperphosphorylation of tau in Alzheimer's disease. Sci. Rep. 2016, 6, 26697. [CrossRef] [PubMed]

93. Vemula, S.; Shi, J.; Hanneman, P.; Wei, L.; Kapur, R. ROCK1 functions as a suppressor of inflammatory cell migration by regulating PTEN phosphorylation and stability. Blood 2010, 115, 1785-1796. [CrossRef] [PubMed]

94. Rodriguez-Ortiz, C.J.; Baglietto-Vargas, D.; Martinez-Coria, H.; LaFerla, F.M.; Kitazawa, M. Upregulation of miR-181 decreases c-Fos and SIRT-1 in the hippocampus of 3xTg-AD mice. J. Alzheimer's Dis. 2014, 42, 1229-1238. [CrossRef] [PubMed]

95. Gao, J.; Wang, W.-Y.; Mao, Y.-W.; Gräff, J.; Guan, J.-S.; Pan, L.; Mak, G.; Kim, D.; Su, S.C.; Tsai, L.-H. A novel pathway regulates memory and plasticity via SIRT1 and miR-134. Nature 2010, 466, 1105. [CrossRef] [PubMed]

96. Zhou, H.; Zhang, R.; Lu, K.; Yu, W.; Xie, B.; Cui, D.; Jiang, L.; Zhang, Q.; Xu, S. Deregulation of miRNA-181c potentially contributes to the pathogenesis of $\mathrm{AD}$ by targeting collapsin response mediator protein 2 in mice. J. Neurol. Sci. 2016, 367, 3-10. [CrossRef] [PubMed]

97. Charrier, E.; Reibel, S.; Rogemond, V.; Aguera, M.; Thomasset, N.; Honnorat, J. Collapsin response mediator proteins (CRMPs). Mol. Neurobiol. 2003, 28, 51-63. [CrossRef]

98. Cole, A.R.; Noble, W.; Aalten, L.v.; Plattner, F.; Meimaridou, R.; Hogan, D.; Taylor, M.; LaFrancois, J.; Gunn-Moore, F.; Verkhratsky, A. Collapsin response mediator protein-2 hyperphosphorylation is an early event in Alzheimer's disease progression. J. Neurochem. 2007, 103, 1132-1144. [CrossRef]

99. Tian, N.; Cao, Z.; Zhang, Y. MiR-206 decreases brain-derived neurotrophic factor levels in a transgenic mouse model of Alzheimer's disease. Neurosci. Bull. 2014, 30, 191-197. [CrossRef]

100. Tapia-Arancibia, L.; Aliaga, E.; Silhol, M.; Arancibia, S. New insights into brain BDNF function in normal aging and Alzheimer disease. Brain Res. Rev. 2008, 59, 201-220. [CrossRef]

101. Chao, M.V. Neurotrophins and their receptors: A convergence point for many signalling pathways. Nat. Rev. Neurosci. 2003, 4, 299. [CrossRef]

102. Nagahara, A.H.; Merrill, D.A.; Coppola, G.; Tsukada, S.; Schroeder, B.E.; Shaked, G.M.; Wang, L.; Blesch, A.; Kim, A.; Conner, J.M. Neuroprotective effects of brain-derived neurotrophic factor in rodent and primate models of Alzheimer's disease. Nat. Med. 2009, 15, 331. [CrossRef]

103. Arancibia, S.; Silhol, M.; Mouliere, F.; Meffre, J.; Höllinger, I.; Maurice, T.; Tapia-Arancibia, L. Protective effect of BDNF against beta-amyloid induced neurotoxicity in vitro and in vivo in rats. Neurobiol. Dis. 2008, 31, 316-326. [CrossRef]

104. Larsen, K.E.; Sulzer, D. Autophagy in neurons a review. Histol. Histopathol. 2002, 17, 897-908. [PubMed] 
105. Boland, B.; Kumar, A.; Lee, S.; Platt, F.M.; Wegiel, J.; Yu, W.H.; Nixon, R.A. Autophagy induction and autophagosome clearance in neurons: Relationship to autophagic pathology in Alzheimer's disease. J. Neurosci. 2008, 28, 6926-6937. [CrossRef] [PubMed]

106. Zhang, Y.; Li, Q.; Liu, C.; Gao, S.; Ping, H.; Wang, J.; Wang, P. MiR-214-3p attenuates cognition defects via the inhibition of autophagy in SAMP8 mouse model of sporadic Alzheimer's disease. NeuroToxicology 2016, 56, 139-149. [CrossRef] [PubMed]

107. Li, F.; Wei, G.; Bai, Y.; Li, Y.; Huang, F.; Lin, J.; Hou, Q.; Deng, R.; Zhou, J.H.; Zhang, S.X. MicroRNA-574 is involved in cognitive impairment in 5-month-old APP/PS1 mice through regulation of neuritin. Brain Res. 2015, 1627, 177-188. [CrossRef] [PubMed]

108. Fujino, T.; Lee, W.-C.A.; Nedivi, E. Regulation of cpg15 by signaling pathways that mediate synaptic plasticity. Mol. Cell. Neurosci. 2003, 24, 538-554. [CrossRef]

109. Fujino, T.; Leslie, J.H.; Eavri, R.; Chen, J.L.; Lin, W.C.; Flanders, G.H.; Borok, E.; Horvath, T.L.; Nedivi, E. CPG15 regulates synapse stability in the developing and adult brain. Genes Dev. 2011, 25, 2674-2685. [CrossRef]

110. Wang, X.; Xu, Y.; Zhu, H.; Ma, C.; Dai, X.; Qin, C. Downregulated microRNA-222 is correlated with increased p27Kip1 expression in a double transgenic mouse model of Alzheimer's disease. Mol. Med. Rep. 2015, 12, 7687-7692. [CrossRef]

111. Toyoshima, H.; Hunter, T. p27, a novel inhibitor of G1 cyclin-Cdk protein kinase activity, is related to p21. Cell 1994, 78, 67-74. [CrossRef]

112. Delobel, P.; Lavenir, I.; Ghetti, B.; Holzer, M.; Goedert, M. Cell-cycle markers in a transgenic mouse model of human tauopathy: Increased levels of cyclin-dependent kinase inhibitors p21Cip1 and p27Kip1. Am. J. Pathol. 2006, 168, 878-887. [CrossRef] [PubMed]

113. Tiribuzi, R.; Crispoltoni, L.; Porcellati, S.; Di Lullo, M.; Florenzano, F.; Pirro, M.; Bagaglia, F.; Kawarai, T.; Zampolini, M.; Orlacchio, A. miR128 up-regulation correlates with impaired amyloid $\beta$ (1-42) degradation in monocytes from patients with sporadic Alzheimer's disease. Neurobiol. Aging 2014, 35, 345-356. [CrossRef] [PubMed]

114. Liu, Y.; Zhang, Y.; Liu, P.; Bai, H.; Li, X.; Xiao, J.; Yuan, Q.; Geng, S.; Yin, H.; Zhang, H. MicroRNA-128 knockout inhibits the development of Alzheimer's disease by targeting PPAR $\gamma$ in mouse models. Eur. J. Pharmacol. 2019, 843, 134-144. [CrossRef] [PubMed]

115. Chen, Y.-C.; Wu, J.-S.; Tsai, H.-D.; Huang, C.-Y.; Chen, J.-J.; Sun, G.Y.; Lin, T.-N. Peroxisome proliferator-activated receptor gamma (PPAR- $\gamma$ ) and neurodegenerative disorders. Mol. Neurobiol. 2012, 46, 114-124. [CrossRef] [PubMed]

116. Landreth, G.; Jiang, Q.; Mandrekar, S.; Heneka, M. PPAR $\gamma$ agonists as therapeutics for the treatment of Alzheimer's disease. Neurotherapeutics 2008, 5, 481-489. [CrossRef] [PubMed]

117. Nicolakakis, N.; Hamel, E. The nuclear receptor PPAR $\gamma$ as a therapeutic target for cerebrovascular and brain dysfunction in Alzheimer's disease. Front. Aging Neurosci. 2010, 2, 21. [CrossRef]

(C) 2019 by the authors. Licensee MDPI, Basel, Switzerland. This article is an open access article distributed under the terms and conditions of the Creative Commons Attribution (CC BY) license (http://creativecommons.org/licenses/by/4.0/). 